\title{
Sorghum Fermentation for Nutritional Improvement
}

\author{
Debabandya Mohapatra*, Manoj Kumar Tripathi, Sumedha Deshpande, Sadvatha R. H \\ ICAR-Central Institute of Agricultural Engineering, Nabi Bagh, Berasia Road, Bhopal, Madhya Pradesh \\ *Email: debabandya@gmail.com
}

\begin{abstract}
Sorghum is one of the top five cereal crops in the world. It has been mostly used as a staple in Africa and Asian countries since ancient times. Its use as gluten free cereal is gaining importance in other developing countries, where it has traditionally been used as feed material and production of bioethanol and other industrial products. The grains are rich in nutrients, have high resistant starch, which makes it ideal for weight loss program. The world consumption pattern has seen a marginal growth, especially in China, USA, and Mexico as these grains are being preferred as non-gluten substitutes for the production of various functional and traditional foods. One of the major deterrents for its use as food is the lower availability of protein, starch, and minerals due to the presence of anti-nutritional factors like tannins and phytic acid. However, processing like fermentation has proven to reduce the anti-nutritional factors, thus improving the nutritional availability and the functional properties of sorghum. During preparation of most traditional dishes by natural or forced lactic acid bacteria fermentation, $\mathrm{pH}$ drops to below 4.0, which helps to prevent the growth of enteropathogenic bacteria, thus rendering the food microbiologically safe. Worldwide, especially in Africa different fermented products have been produced from sorghum. In India as well as in other countries, efforts are being made to replace the high glycemic index cereals such as rice and wheat with sorghum to prepare traditional ethnic foods through fermentation. There is enough opportunity to include this grain in the daily diets for better health.
\end{abstract}

Keywords: Sorghum, nutrition, mineral availability, fermentation

\section{Introduction}

Sorghum (Sorghum bicolor L. Moench), also known as Jowar in India, great millet and guinea corn in West Africa, kafir corn in South Africa, dura in Sudan, mtama in eastern Africa, milo or milo-maize in USA, and kaoliang in China, had been an important staple in the semi-arid tropics of Asia and Africa for centuries. Sorghum is believed to be originated in North Africa about 3000 BC. As evident from the wall paintings of that era, it was cultivated in Egypt by 2200 BC. From there, it is believed to have spread throughout Africa, India, and the Middle East and reached China and America more recently (Chigumira 1992). However, some historians differ about the antiquity of sorghum (De Wet \& Huckabay 1967). Whatever the history agrees or disagrees, it is a fact that in the present time, sorghum is considered to be one of the top five cereal crops grown all over the world especially in arid and semiarid regions. Grain sorghum is used for the preparation of various traditional foods in Africa and Asia and as feed material in developing countries; the green crop is used for grazing animals; the stalk of sweet sorghum variety is used for extraction of sweet syrup for the production of ethanol. Moreover, the plant residue is also used for making fencing, broom, pet food to name a few. This crop requires very less amount of water as compared to rice and wheat for cultivation and usually adapted to arid and heat stress conditions.

\subsection{Status of Sorghum in the World Economy}

Post-green revolution, India has witnessed a constant decline in production of millets. According to a report of Unites States Department of Agriculture (2016), production of sorghum in India has declined from 12.914 million tonnes in the year 1989 to 5.5 million tonnes in 2015. India is the fourth largest sorghum producing country after the USA (15.158 million tonnes), Mexico (7.15 million tonnes), Nigeria (6.15 million tonnes), and Sudan (5.5 million tonnes). China (10 million tonnes), Mexico (7.6 million tonnes), Nigeria (6.05 million tonnes), USA (5.84 million tonnes), Sudan (5.8 million tonnes), India (5.35 
million tonnes) are the top sorghum consumers in the year 2015. Top three sorghum exporters are China (7 million tonnes), Japan (1 million tonnes) and Mexico (0.5 million tonnes). The top three exporters of sorghum are USA (8.255 million tonnes), Argentina (1.1 million tonnes) and Australia 1.0 million tonnes). Sorghum as feed is mostly consumed in China (7.8 million tonnes), Mexico (7.5 million tonnes) and USA (3.302 million tonnes).

\subsection{Nutritive Value of Sorghum}

Sorghum grain is a rich source of macronutrients (carbohydrates, proteins, and fat) and micronutrients (minerals and vitamins). It has about $70 \%$ carbohydrate, $3.5 \%$ fat and $11 \%$ protein. The protein content is about double than the brown rice and comparable to Rye and wheat (Table 1). The total dietary fiber content in sorghum is more than $20 \%$, much higher than any other major cereal crops like rice and wheat (Table 2). It is rich in magnesium, iron, manganese and phosphorus. A comparative mineral composition of different cereal grains is presented in Table 3. Sorghum grains contain resistant starch, which makes it interesting for obese and diabetic people, as the digestibility of whole sorghum is slower than other major cereals, leading the slow release of glucose into the blood. Therefore, the energy released is fully utilized and prevents accumulation of fat. Sorghum is also recommended as gluten-free food for celiac patients. The $\alpha$-amylase and $\beta$-amylase activities of malted sorghums varieties are similar to those of barley. Thus, the grain shows enough potential to be adopted in the production of various agro-food and industrial products (Dicko et al. 2006). Domestication of paddy and wheat crops had deterred the use of sorghum and other millets as food crop; however, currently, people are shifting towards high dietary fiber foods for their apparent health benefits. Sorghum grain is also a rich source of various phytochemicals such as tannins, phenolic acids, anthocyanins, phytosterols and policosanols (Awika \& Rooney 2004), which have health-promoting activities, have anti-cancer, anti-tumour properties, antidiabetic and anti-obesity properties. The antioxidants present in the grains are comparable to those present in fruits (Awika \& Rooney 2004; Kamath et al. 2004). The antioxidants present in various cereals are presented in Table 4.

Table 1. Chemical composition (\% dry basis) of different cereal grains and millets

\begin{tabular}{l|l|l|l|l}
\hline Cereal & Carbohydrate & Protein $(\mathbf{N} \times \text { factor })^{*}$ & Total ash & Crude fat \\
\hline Barley & $53.6 \pm 1.0$ & $19.4 \pm 0.4$ & $2.88 \pm 0.04$ & $2.31 \pm 0.1$ \\
\hline Brown rice & $79.2 \pm 2.08$ & $6.98 \pm 0.07$ & $1.96 \pm 0.11$ & $1.20 \pm 0.68$ \\
\hline Finger millet & 61.00 & 7.0 & 2.0 & 1.5 \\
\hline Foxtail millet & $72.3 \pm 0.3$ & $11 \pm 0.2$ & $2.4 \pm 0.1$ & $4.6 \pm 0.3$ \\
\hline Millet & $67.4 \pm 1.3$ & $8.8 \pm 0.1$ & $1.82 \pm 0.03$ & $4.22 \pm 0.2$ \\
\hline Proso millet & $70.0 \pm 0.8$ & $10.9 \pm 0.2$ & $3.3 \pm 0$ & $3.8 \pm 0.2$ \\
\hline Rye & $58.0 \pm 1.0$ & $13.3 \pm 0.2$ & $1.96 \pm 0.03$ & $2.53 \pm 0.1$ \\
\hline Sorghum & $67.7 \pm 1.2$ & $12.1 \pm 0.1$ & $1.87 \pm 0.03$ & $3.32 \pm 0.1$ \\
\hline Wheat (Hard) & $77.4 \pm 1.7$ & $13.5 \pm 0.3$ & $0.56 \pm 0.01$ & $0.98 \pm 0.03$ \\
\hline Wheat (soft) & $77.9 \pm 1.8$ & $11.0 \pm 0.2$ & $0.71 \pm 0.01$ & $0.86 \pm 0.03$ \\
\hline
\end{tabular}

*Nitrogen-to-protein conversion factors are: 5.7 for wheat flour, 5.83 for rye and barley whole grain, and 5.95 for brown rice, 6.25 for millet and sorghum whole grain

(Ref: Ragaee et al. 2006; Moongngarm \& Saetung 2010; Dharmaraj \& Malleshi 2011; Devisetti et al. 2014)

Table 2. Dietary fibres composition (\% dry basis) of sorghum and other cereals

\begin{tabular}{l|c|c|c|c}
\hline Cereal & Soluble dietary fibre & Resistant starch & Insoluble dietary fibre & Total dietary fibre \\
\hline Barley & $2.56 \pm 0.03$ & $0.23 \pm 0.01$ & $22.07 \pm 0.41$ & $24.63 \pm 0.52$ \\
\hline Brown rice & - & - & - & $1.13 \pm 0.16$ \\
\hline Finger millet & 1.4 & - & 15.7 & - \\
\hline Foxtail millet & $1.1 \pm 0.1$ & - & $19.7 \pm 0.5$ & $20.8 \pm 0.4$ \\
\hline Millet & $1.45 \pm 0.01$ & $1.96 \pm 0.01$ & $13.50 \pm 0.32$ & $14.95 \pm 0.41$ \\
\hline
\end{tabular}




\begin{tabular}{l|c|c|c|c}
\hline Proso millet & $1.1 \pm 0.1$ & & $18.4 \pm 0.5$ & $19.4 \pm 0.4$ \\
\hline Rye & $3.70 \pm 0.02$ & $0.20 \pm 0.01$ & $14.07 \pm 0.23$ & $17.77 \pm 0.53$ \\
\hline Sorghum & $1.42 \pm 0.01$ & $1.77 \pm 0.02$ & $19.59 \pm 0.41$ & $21.01 \pm 0.41$ \\
\hline Wheat (hard) & $1.61 \pm 0.01$ & $0.20 \pm 0.02$ & $2.98 \pm 0.01$ & $4.59 \pm 0.21$ \\
\hline Wheat (Soft) & $1.78 \pm 0.01$ & $0.55 \pm 0.01$ & $1.87 \pm 0.01$ & $3.65 \pm 0.11$ \\
\hline
\end{tabular}

(Ref: Ragaee et al. 2006; Moongngarm \& Saetung 2010; Dharmaraj \& Malleshi 2011; Devisetti et al. 2014)

Table 3. Mineral composition $(\mathrm{mg} / \mathrm{kg})$ of sorghum and other cereals

\begin{tabular}{l|c|c|c|c|c|c|c|c|c|c}
\hline cereals & $\mathbf{P}$ & $\mathbf{K}$ & $\mathbf{M g}$ & $\mathbf{C a}$ & $\mathbf{N a}$ & $\mathbf{Z n}$ & $\mathbf{F e}$ & $\mathbf{M n}$ & $\mathbf{C u}$ & $\mathbf{C r}$ \\
\hline Barley & 4570 & 4572 & 1971 & 736.2 & 238.4 & 74.2 & 128.4 & 9.2 & 5.7 & 0.9 \\
\hline Brown Rice & $480-4300$ & $125-3000$ & $39.5-1660$ & $26-500$ & $17-340$ & $6-31$ & $2-57$ & $2-60$ & $0.5-6$ & - \\
\hline Finger millet & 2440 & - & - & 3210 & - & 21 & 60 & - & 16 & - \\
\hline Millet & 2879 & 2798 & 1488 & 508.6 & 60.89 & 65.9 & 199.8 & 8.1 & 3.4 & 7.7 \\
\hline Rye & 3620 & 3570 & 1328 & 348.7 & 67.2 & 30.6 & 44 & 24.4 & 2.9 & 0.7 \\
\hline Sorghum & 349.9 & 239.9 & 187.7 & 27.3 & 4.6 & 3.1 & 10.6 & 1.2 & 0.2 & 0.8 \\
\hline Wheat (hard) & 3498 & 826.2 & 301.2 & 159.5 & 46 & 30.8 & 13.2 & 5.2 & 1.4 & 0.1 \\
\hline Wheat (soft) & 977.6 & 1225 & 306.5 & 202.2 & 38.4 & 7.6 & 13.9 & 8.1 & 1.6 & 0.001 \\
\hline
\end{tabular}

(Ref: Ragaee et al. 2006, Heinemann et al. 2006; Dharmaraj \& Malleshi 2011)

Table 4. Total phenols content and antioxidant properties of sorghum and other cereals

\begin{tabular}{l|c|c|c}
\hline Cereal & $\begin{array}{c}\text { Total phenols as gallic } \\
\text { acid equivalent }(\mu \mathrm{g} / \mathrm{g})\end{array}$ & $\begin{array}{c}\text { DPPH scavenging capacity } \\
\text { at } 10 \mathrm{~min}(\mu \mathrm{mole} / \mathrm{g})\end{array}$ & $\begin{array}{c}\text { ABTS scavenging capacity at } \\
3 \mathrm{~min}(\mu \mathrm{mole} / \mathrm{g})\end{array}$ \\
\hline Barley & $879 \pm 24.0$ & $21.00 \pm 0.83$ & $14.9 \pm 0.61$ \\
\hline Brown Rice & $703 \pm 83.1^{\mathrm{a}}$ & $12.99-76.38^{\mathrm{b}}$ & - \\
\hline Millet & $1387 \pm 13.3$ & $23.83 \pm 0.67$ & $13.0 \pm 0.43$ \\
\hline Rye & $1026 \pm 16.9$ & $12.17 \pm 0.50$ & $51.7 \pm 0.57$ \\
\hline Sorghum & $4128 \pm 9.3$ & $195.8 \pm 8.82$ & $8.8 \pm 0.39$ \\
\hline wheat (Hard) & $562 \pm 28.8$ & $4.33 \pm 0.17$ & $8.3 \pm 0.31$ \\
\hline wheat (Soft) & $501 \pm 25.5$ & $4.17 \pm 0.17$ & $2015)$ \\
\hline
\end{tabular}

(Reference: Ragaee et al. 2006; ' Moongngarm \& Saetung 2010; 'bompong et al. 2011; Zhang \& Liu 2015)

\subsection{Bioactive Compounds in Sorghum}

Phenolic acids, tannins, and flavonoids are major bioactive phenolic compounds present in sorghum (Dykes \& Rooney 2006). Those bioactive compounds found in sorghum are more diverse in nature and are present in higher amount in sorghum than in other cereal crops like wheat, barley, rice, maize, rye, and oats (Ragaee et al. 2006). The presence of higher amount of proanthocyanidins, 3deoxyanthocyanidins, and flavan-4-ols in sorghum varieties resistant to biotic and abiotic stresses than susceptible varieties (Dicko et al. 2005) suggested that these crops have better resistivity to adverse conditions during growing, which was possible through the synthesis of these bioactive compounds. Though millets including sorghum are nutritionally rich, their bioavailability is limited, which is the biggest shortfall for fully utilizing these crops as a part of the human diet (Faria et al. 2013; Hole et al. 2012). Different factors affecting the bioavailability of phenolic compounds can be listed as environmental factors, a method of food processing, type of food matrix, and interaction of the biomolecule with other compounds and polyphenols (D'Archivio et al. 2010). Faria et al. (2013) observed that catabolites of phenolic compounds, not absorbed in the small intestine passed into the large intestine. It was postulated that these compounds can interfere with the activities of the colon microbiota.

The content of phenolic acids in sorghum varieties varies between 135.5 and $479.40 \mu \mathrm{g} / \mathrm{g}$ (Chiremba et al. 2012), with major amounts of the protocatechuic (150.3 to $178.2 \mu \mathrm{g} / \mathrm{g}$ ) and ferulic (120.5 to 173.5 
$\mu \mathrm{g} / \mathrm{g}$ ) acids and small amounts of the p-coumaric (41.9 to $71.9 \mu \mathrm{g} / \mathrm{g}$ ), syringic (15.7 to $17.5 \mathrm{\mu g} / \mathrm{g}$ ), vanillic ( 15.4 to $23.4 \mathrm{\mu g} / \mathrm{g}$ ), gallic (14.8 to $21.5 \mathrm{\mu g} / \mathrm{g}$ ), caffeic (13.6 to $20.8 \mathrm{\mu g} / \mathrm{g}$ ), cinnamic (9.8 to 15.0 $\mathrm{\mu g} / \mathrm{g}$ ), and p-hydroxybenzoic (6.1 to $16.4 \mathrm{\mu g} / \mathrm{g}$ ) acids (Afify et al. 2012c). Comparatively, phenolic acids present in wines, fruits, and vegetables have better bioavailability than the cereals. The majority of phenolic acids found in free or as conjugated forms can be hydrolysed in the upper intestinal tract (Hole et al. 2012). On the contrary, phenolic acids present in cereals like sorghum, are mostly bound to lignin (Hole et al. 2012). These bound phenolic acids are not readily hydrolysed by human digestive enzymes thus limiting their bioavailability; however, they are fermented by the microbiota of the colon (Hole et al. 2012).

Tannins are complex phenolics or secondary metabolites found in many plants. These compounds are mainly associated with plants defense mechanism against insects, ruminants, pathogens, and climate stress (Kaufman et al. 2013). These compounds are present in the outer layer and testa of the millets like pigmented sorghum varieties (Wu Yuye et al. 2012). The tannins content, type, and their distribution pattern vary in millets, which are influenced by the genetic and environmental factors (Dykes et al. 2009; Taleon et al. 2012). They are classified as type I (no significant levels), type II (tannins that are extractable only in acidified methanol) and type III (tannins that are extractable in methanol and acidified methanol) (Hahn \& Rooney, 1986). Almost all of the tannins in sorghum are condensed and constituted by oligomers or polymers of catechins (Wu Yuye et al. 2012). The total flavones of the sorghum vary from 0 to $386 \mathrm{\mu g} / \mathrm{g}$ (on average, $87 \mathrm{\mu g} / \mathrm{g}$ ), with a prevalence of aglycone forms of luteolin and apigenin (Dykes et al. 2011). The main flavanones of sorghum are the aglycone forms of eriodictyol and naringenin (Dykes et al. 2011). The smallest contents are found in white varieties and the largest contents are observed in those with lemon-yellow pericarp (474 to $1780 \mathrm{\mu g} / \mathrm{g}$ ) (Dykes et al. 2011).

Though tannins are known to have anti-nutritional properties, their radical scavenging ability is 1530 times more effective than other polyphenolics (Hagerman et al. 1998). The oligomers of tannins in foods contribute up to $19 \%$ of the antioxidant capacity of the diet and have immunomodulatory, anticancer, antioxidant, antiradical, anti-inflammatory, vasodilatory, cardio-protective, anti-thrombotic, and anti-UV properties (Floegel et al. 2010).

Stilbenes are a small family of phenolic compounds which are derived from the phenylpropanoid pathway (Chong et al. 2009). The total content of stilbenes correlates with the colour of the grain and is present in smaller quantities in white varieties. White sorghum contains traces of trans-piceid (up to 0.1 $\mathrm{mg} / \mathrm{kg}$ ) and trans-resveratrol is absent, while in red sorghum, these two classes are present (Br̈ohan et al. 2011). Polycosanols and phytosterols are associated with the lipid fraction of the sorghum (Zbasnik et al. 2009). Thus, these compounds have been studied mainly in lipids extracted from dry sorghum obtained after alcohol production. The content of sorghum phytosterols (4.13 to $24.45 \mathrm{\mu g} / \mathrm{g}$, dry weight basis) is affected by growing conditions (Chung et al. 2013). Sorghum grains are a relatively rich source of phytosterols when compared with fruits, vegetables, and other cereal grains commonly found in the food supply. Presently more than 200 sterols reported in vegetables, 3 have been identified in sorghum (sitosterol: 44.8 to $48.2 \%$; campesterol: 26.1 to $38.0 \%$ and stigmasterol: $17.3 \%$ to $25.6 \%$ ) (Wang et al. 2007; Ye et al. 2010).

Numerous reports on reduced weight gain of animals (rats, pigs, rabbits, poultry) fed high tannin sorghum are available (Muriu et al. 2002). The mechanisms by which tannin sorghums reduce nutritive value include binding of food proteins (Hagerman \& Butler 1981) and carbohydrates (Naczk \& Shahidi 1997) into insoluble complexes that cannot be broken down by digestive enzymes. Another mechanism involves the direct binding of digestive enzymes including sucrose, amylases, trypsin, chymotrypsin and lipases (Al-Mamary et al. 2001), thus inhibiting their activity. Effects of the sorghum tannins on animal weight gain depend on levels fed as well as animal species. Al-Mamary et al. (2001) found the addition of $1.4 \%$ catechin equivalents (CE) sorghum to rabbit diet had no effect on growth rate and weight gain, whereas, at a $\mathrm{CE}$ of $3.5 \%$, there was a marked decrease in live weight gain and feed conversion ratio.

Positive effects of sorghum consumption on cancer have been well documented. Van Rensburg (1981) reported that sorghum consumption consistently correlated with low incidences of oesophageal cancer in various parts of the world, whereas wheat and corn consumption correlated with elevated incidences. Such regions also had deficiencies of certain minerals and vitamins in their diets. In attempting to explain this phenomenon, the author proposed (with considerable evidence) that the nutrient deficiencies were responsible for the high oesophageal cancer incidences, and that sorghum and millet 
consumption promoted resistance to esophageal cancer risk. In vitro studies have also revealed anticarcinogenic properties of sorghum. Grimmer et al. (1992) demonstrated anti-mutagenicity of sorghum polyphenol extracts. They found the high molecular weight procyanidins (tannins) had the highest antimutagenic activity compared to lower molecular weight tannins. Gomez-Cordovez et al. (2001) showed that sorghum tannins had anti-carcinogenic activity against human melanoma cells, as well as positive melanogenic activity (Eller et al. 1996).

\subsection{Anti-nutritional Factors in Sorghum}

One of the major impediments for adopting sorghum as staple Vis-a-vis major cereal based products is its lower nutritional status and inferior organoleptic qualities, which is attributed to the presence of anti-nutritional factors such as tannins and phytic acids. As compared to other major cereals, sorghum has the lowest starch digestibility, which is attributed to the presence of hard peripheral endosperm layer rich in pigments and phenolics. Moreover, sorghum poor digestibility of proteins on wet cooking as compared to rice, wheat, and maize i.e. about $46 \%$ in contrast to 66-81\% (Axtell et al. 1981). Poor sorghum protein digestibility is due to the exogenous factors such as, grain organizational structure, polyphenols, phytic acid, starch and non-starch polysaccharides and endogenous factors such as disulphide and non-disulphide cross-linking of enzymatically resistant protein polymers, kafirin hydrophobicity and changes in protein secondary structure (Fombang et al. 2005; Taylor \& Emmambux 2010). It was proposed that cross-linking between $\gamma$ - and $\beta$-kafirin proteins, those residing in the peripheral region of protein body, with centrally located major storage protein, $\alpha$-kafirin, or between $\gamma$ or $\beta$-kafirin and $\alpha$-kafirin caused protein indigestibility (Duodu et al. 2003).

Dry sorghum grains contain tannin and small cyanide. These phenolics impart dark colour, bitterness, and astringency in the prepared food, thus affecting the sensory quality of sorghum based food (Kobue-Lekalake et al. 2007). Moreover, these tannins interact with protein involving hydrogen bonding and hydrophobic interactions. Pepsin-indigestible proteins in sorghum were mainly prolamin proteins (Hamaker et al. 1987), which bind strongly to sorghum tannins and cause reduced protein digestibility. It is reported that the degradation of phytic acid in high tannin content sorghum is lower as compared to that in low tannin variety (Hurrell et al. 2003); this observation indicated that presence of tannin also affects the other anti-nutritional factors, the way they are bonded with other chemical constituents.

Phytates are major anti-nutritional compounds identified in sorghum (Abdel-Rahman \& Osman 2011; Afify et al. 2011). The phytate molecule, containing six phosphate groups, is highly charged and has the capability to form insoluble complexes with proteins leading to reduced digestibility. In addition, some varieties have protease inhibitors (trypsin, chymotrypsin, and amylase) and lectins (Abdel-Rahman \& Osman 2011; Raimi et al. 2012). These phytochemicals decrease the digestibility of proteins and carbohydrates and mineral bioavailability.

Protein digestibility of uncooked flour ranges about 40-93\%; whereas, on cooking, digestibility decreases to about 18-73\% for whole sorghum flour and decorticated flours of different varieties (Duodu et al. 2003). The protein digestibility of cooked sorghum can be improved through dry cooking (popping), malting, irradiation, fermentation, flaking, extrusion etc. (Duodu et al. 2003; Fombang et al. 2005).

\section{Sorghum Fermentation}

Fermentation is an age-old practice by a human being, so as to induce favourable biochemical reactions caused by microorganisms in the targeted food. Fermentation brings change in flavour, texture and nutritive value of the food. Traditionally, rice, black gram, sorghum, millets and other grains are fermented naturally by lactic acid bacteria (LAB) for the preparation of different food and beverages. Fermentation using yeast also has an importance in preparing specialty foods like bread. The advantages of LAB fermentation are many, which include inhibition of enteropathogenic bacteria, improvement of palatability and acceptability as a results of change in texture, flavour and colour, enrichment of nutrients by microbial synthesis of vitamins and reduction in anti- nutritional factors like phytic acid and tannins, improvement in protein and starch digestibility, increase oil-binding capacity, 
emulsifying capacity and emulsifying stability, decreased the water-binding capacity (Kazanas \& Fields 1981; Oyewole 1997; Elkhalifa et al. 2005). These effects are discussed in the following sections.

\subsection{Fermentation and Protein Digestibility}

Cooked sorghum protein is less digestible than other cooked cereal proteins (Hamaker et al. 1984). Fermentation causes structural changes in the sorghum storage proteins like prolamins and glutelins so that they are more susceptible to digestion by the pepsin enzyme. Many types of research indicated that there was an increase in globulin and albumin fractions during fermentation, while prolamin and other protein fractions fluctuated (El Khalifa \& El Tinay 1994; Hassan \& El Tinay 1995). The improvement in protein digestion though fermentation is attributed to the degradation of tannins (Yousif \& El Tinay 2001). Kazanas and Fields (1981) observed that natural LAB fermentation of whole ground sorghum resulted in an increase in available amino acids like lysine/leucine, isoleucine, methionine, vitamins like niacin, riboflavin, and thiamine. Moreover, the protein quality increased significantly as a result of fermentation. Chavan et al. (1988) observed an increase in proteins, free amino acids, soluble proteins and in vitro protein digestibility of sorghum meal within $24 \mathrm{~h}$ fermentation. Fermentation and germination has been reported as good options for increasing digestibility of sorghum proteins (Axtell et al. 1981; Wedad et al. 2008), reducing the anti-nutritional factors such as tannin and phytic acid and improving the availability of minerals as compared to raw sorghum (Idris et al. 2005; Abdelseed et al. 2011; ELKhier \& Abd-Al Raheem 2011). Naturally fermented sorghum porridge, a traditional African food, had better in vitro protein digestibility and in vitro insoluble protein digestibility (Taylor \& Taylor 2002). Traditional Saudi Arabia bread Khamir is prepared through fermentation of milled sorghum flour. Fermentation not only improves the in vitro protein digestibility (Osman, 2004) but also eliminates the problems in baking. During sourdough fermentation, proteins from the dough liquid are degraded to peptides smaller than kafirin monomers $(<19 \mathrm{kDa})$. Schober et al. (2007) observed fermentation of sorghum sourdough, caused a significantly higher resistance to deformation after gelatinization; with a stronger gel rendering the sorghum bread its desirable characteristics.

\subsection{Fermentation and Starch Digestibility}

Most starches exist inside the endosperm of cereals enmeshed in a strong protein matrix. Therefore, their digestibility is affected by the extent of starch-protein interaction, plant species, physical form of the granule and type of starch and presence of inhibitors such as tannins (Rooney \& Pflugfelder 1985; Zhang \& Hamaker 1998; Shin et al. 2004; Benmoussa et al. 2006; Singh et al. 2010). Sorghum tannins, predominately proanthocyanidins, interact strongly with amylose and linear fragments of amylopectin during cooking and thus decrease their bioavailability and digestibility (Barros et al. 2012). During LAB fermentation extracellular amylase is produced and helps ferment starch (Reddy et al. 2008). LAB fermentation thus improves starch digestibility and reduces the resistant starch and total starch (El Khalifa et al. 2004). Natural fermentation with LAB also reduced the amylase inhibition activities by $75 \%$ during $24 \mathrm{~h}$ fermentation, which would otherwise have interfered with starch digestibility and availability (Osman. 2004). LAB fermentation also reportedly decreases tannin content, affects the protein-starch matrix; thus, improves the starch digestibility (Hassan \& El Tinay 1995).

\subsection{Fermentation and Anti-nutritional Factors}

During LAB fermentation, phenolic acids, phenolic acid esters, and flavonoid glucosides are metabolized (Svensson et al. 2010), which influences the nutritional value and the molecular interactions. LAB fermentation reduces the tannin content (El Khalifa \& El Tinay 1994; Hassan \& El Tinay 1995; Wedad et al. 2008). Towo et al. (2006) had observed that fermentation with lactic acid bacteria of tannin sorghum gruel reduced the polyphenol content by about $50 \%$ with respect to the raw material. However, the reduction was up to $73 \%$ when enzymes like phytase and polyphenol oxidase were used. Fermentation has proven to be better in reducing the phytate level than the malting process of grain sorghum (Makokha et al. 2002). El Khalifa and El Tinay (1994) reported a reduction of tannin content by $92 \%$ in high tannin content variety during $14 \mathrm{~h}$ fermentation of grain sorghum and the phytate content in the raw sorghum flour $(12.1 \mathrm{\mu mol} / \mathrm{g})$ was significantly reduced after soaking and boiling (9.3 
$\mu \mathrm{mol} / \mathrm{g})$ and fermentation $(7.4 \mu \mathrm{mol} / \mathrm{g})$. The addition of germinated power flour to the gruel had better efficiency in reducing the polyphenolic and phytic acid content. Mahgoub and Elhag (1998) studied the effect of milling, soaking, malting, heat-treatment and fermentation on phytate level of four Sudanese sorghum cultivars. The reduction in phytic acid level was about $57-80 \%$ of different varieties of sorghum after $12 \mathrm{~h}$ of fermentation. They also observed that malting reduces the phytic acid content by $68-83 \%$, whereas cooking reduces the phytic acid content only by $17.9-37.5 \%$ and soaking for $12 \mathrm{~h}$ the reduction was in the tune of $8.2-14.4 \%$ and that level increased to $57-60 \%$ when the soaking time increased up to 24h. Similar observations were made by Wedad et al. (2008), who reported the decrease in tannin and phytic acid level from $36 \%$ to $0.04 \%$ and 181 to $44.24 \mathrm{mg} / 100 \mathrm{~g}$, respectively in fermented cooked sample after $16 \mathrm{~h}$ of fermentation.

\subsection{Fermentation and Bioavailability of Minerals}

Since earlier times, fermentation is used as a tool to improve the bioavailability of nutrients in vegetable food (Svanberg \& Lorri 1997). The presence of polyphenolic compounds like tannin and phytic acid in vegetable food affects the bioavailability of minerals like Iron, Calcium, Manganese, Zinc, Phosphorus etc. (Sandberg 1991; Makokha et al. 2002; Umeta et al. 2005). LAB fermentation was observed to improve the iron bioavailability from 4 to $9 \%$ in sorghum (Svanberg et al. 1993). Hydrolysis of phytate by the phytase enzyme produces various inositol phosphates containing 1-5 phosphate groups, during fermentation; thereby causing little or no interference in the binding of minerals like $\mathrm{Zn}$, $\mathrm{Ca}$ and $\mathrm{Fe}$, resulting in their improved bioavailability in the ingested food (Sandberg 1991; Kruger et al. 2012). Towo et al. (2006) observed that the bioavailability of iron did not change during fermentation of the sorghum gruel, however with the addition of enzymes and germinated flour to the gruel significantly increased the iron bioavailability from $1 \%$ to 3.1\%. Makokha et al. (2002) observed a decrease in phytic acid to $64 \%$ after $96 \mathrm{~h}$ fermentation and improvement in the available iron, calcium, and manganese.

\subsection{Fermentation and Enteropathogenic Bacteria}

Studies have proved that consumption of fermented cereal gruel having $\mathrm{pH}$ less than 4 , can reduce the presence of enteropathogenic bacteria in human (Gibson \& Wang 1994; Kingamkono et al. 1999). LAB produces bacteriocin, hydrogen peroxide, ethanol and organic acids and decreases the $\mathrm{pH}$ of foods in which they grow, thus inhibiting the growth of enteropathogenic bacteria (Adams \& Nicolaides 1997). Svanberg et al. (1992) fermented maize and sorghum gruel and observed that the $\mathrm{pH}$ dropped down to about 3.8; moreover presence of viable LAB indicated the effect of bacteriocin on the reduction of gram +ve bacteria. Similar kinds of observations were made by Kingamkono et al. (1994). Fermentation of low tannin and high tannin sorghum with starter culture decreased the $\mathrm{pH}$ of the gruel to $<4$ within 24-48h, resulting in inhibition of enteropathogenic bacteria. Fermentation involving the production of acetic acid also makes the food safe. Hence preparation of alcoholic beverages from sorghum and other cereals renders the drink safe. Fermentation involving LAB culture is can inhibit the growth of enteropathogenic bacteria like Campylobacter, Salmonella, Shigella, enterotoxigenic Escherichia Coli (ETEC), Staphylococcus and Bacillus with 24h of incubation (Kingamkono et al. 1995). Hence, food fermentation process involving LAB for sufficiently long time can be regarded as safe.

\section{Utilization of Fermented Sorghum in Food and Beverages}

Sorghum, like other cereals, is an excellent source of starch and protein and can be processed into starch, flour, grits and flakes which can be used to produce a wide range of food, feed, and industrial products. It can also be malted and therefore can be processed into malted foods, beverages, and beer. Cakes, cookies, pasta, a parboiled rice-like product and snack foods have been successfully produced from sorghum. The food uses of sorghum are still mostly traditional and the methods of processing may involve the use of wet or dry heat (Murty \& Kumar 1995). Porridges appear to be the most common types of food prepared from sorghum. A range of porridges of varying consistencies (soft or thick) may be prepared from fermented or non-fermented sorghum meal (Murty \& Kumar 1995). Porridge preparation involves cooking the meal with boiling water and the process varies considerably depending 
on the type of porridge being produced (Taylor et al. 1997). Flatbread and alcoholic beverages are also produced from sorghum. Sorghum grains are also popped and consumed as snacks or delicacies. Sorghum grains also partially or fully replace rice, wheat, soybean and other cereals for the production of traditional fermented foods like idli, dosa, uttapam, vada, porridqes, tempeh (Lyimo 2000), gowe (Laetitia et al. 2005) and so on, in several Asian and African Countries (Hesseltine 1979).

Several traditional fermented foods like idli, dosa, dhokla, appam, and kalliappam are reportedly prepared from sorghum. Idli and dosa are few of the fermented foods based on rice and black gram, however, the emphasis is being given in sorghum producing states of India to incorporate this grain for better nutritional value as these millets had better protein, fiber, fat content as compared to rice-based fermented products. Processing steps like decortication, germination, and fermentation reduce phytic acid and tannin content, making these products acceptable (Raghavendra et al. 1979; Krishnamoorthy et al. 2013). Nazni and Shalini (2010) prepared idli using (i) rice and black gram mixture, (ii) partially replaced rice with sorghum and (iii) fully replaced rice with sorghum. They observed that though the softness of the sorghum $i d l i$ was less than the rice $i d l i$ and mixed $i d l i$, the protein content was higher in mixed $i d l i$, followed by sorghum $i d l i$ and rice $i d l i$. Fat content was highest in sorghum $i d l i$, followed by mixed and rice $i d l i$. The energy content of sorghum idli was the lowest as compared to rice $i d l i$ and mixed $i d l i$. Minerals like calcium, iron were highest in the sorghum $i d l i$ as compared to mixed and rice $i d l i$. On the other hand, carbohydrate content was lowest in sorghum $i d l i$, followed by rice and mixed $i d l i$. Though organoleptically people preferred rice $i d l i$, the mixed $i d l i$ and sorghum $i d l i$ were not rejected and scored over 7.0. Asha et al. (2005) too incorporated sorghum and moth bean in fermented foods like $i d l i$ and dosa with enhancement in protein and other nutrient content. Since sorghum has high resistant starch content, the glycemic index of sorghum incorporated fermented foods has a lesser glycemic index as compared to other cereal based foods like $i d l i$. Jahan et al. (2013) observed that glycemic index of $i d l i$ prepared from sorghum grits was about 51.2 as a contrast to 56.3 that was prepared from rice grits. This finding supports the fact that fermented food like $i d l i$ can be prepared from sorghum by replacing rice for people with diabetics.

A variety of traditional fermented food products like sour bread, porridge, alcoholic and non-alcoholic beverages are produced in many regions of Africa and Asia, every region has their own protocol. Some of the sorghum-based traditional fermented food and beverages are consumed all over the world and the microorganisms associated with them are presented in table 5.

\section{Conclusions}

Sorghum is one of the staple foods in most African and Asian countries, but the emphasis on high yielding cereal crops like wheat and rice, had made it almost disappear from the world food habit. Though in the recent years there is a decline in the production of this grain, however, it is gaining a foothold in the feed industry and biofuel industry in the developed countries. Climate change has also put pressure in the non-sorghum growing regions to adopt this grain as it requires less water as compared to rice and wheat. This gluten free grain is rich in mineral, resistant starch, and polyphenols, which makes it ideal for diabetic and gluten sensitive people. However, the presence of some antinutritional factors like phytic acid and tannin has put constraint over its use as food, as these chemicals prevent bio-accessibility and digestibility of protein, starch, and minerals. Processing conditions like fermentation improve the digestibility of starch, protein and mineral availability of this food. Perhaps that is the reason why sorghum is mainly consumed in the fermented form in African traditional foods and beverages. With suitable processing, the adverse effect of the polyphenolic compounds can be reduced so that the grains can have diverse application in the human diet. 
Table 5. Sorghum based fermented foods, and beverages consumed around the world, their preparation methods and microorganisms involved

\begin{tabular}{|c|c|c|c|c|c|}
\hline Product & Procedure of preparation & Microorganisms involved & Uses & Country & Reference \\
\hline Aceda Nasha & $\begin{array}{l}\text { Whole grain sorghum flour was } \\
\text { fermented for about } 3 \text { days, dried } \\
\text { at } 70^{\circ} \mathrm{C} \text { and ground to make } \\
\text { flour. Aceda is prepared by } \\
\text { boiling to a stiff porridge and } \\
\text { Nasha is prepared to a thin } \\
\text { porridge for weaning food }\end{array}$ & $\begin{array}{l}\text { Lactobacillus } \\
\text { spp, Acetobacter spp, and } \\
\text { Saccharomyces }\end{array}$ & $\begin{array}{l}\text { Thick pudding } \\
\text { a snack / Thin } \\
\text { Porridge as } \\
\text { weaning food }\end{array}$ & Sudan & $\begin{array}{l}\text { Ibrahim et al. } \\
2005\end{array}$ \\
\hline $\begin{array}{l}\text { Amgba/ } \\
\text { bilbili }\end{array}$ & $\begin{array}{l}\text { Germinated grains are sundried, } \\
\text { and the malted grains are ground } \\
\text { and steeped in water with } \\
\text { stirring, the solution is decanted, } \\
\text { to separate the supernatant and } \\
\text { residue. Residue is cooked for } 2 \mathrm{~h} \\
\text { and then mixed with the } \\
\text { supernatant and homogenised, } \\
\text { left to stand overnight in open } \\
\text { air. Separated supernatant, and } \\
\text { filtered liquid are mixed to form } \\
\text { the wort. Wort is boiled for } 5 \text { h } \\
\text { and allowed to cool. Pitch / or } \\
\text { culture is added to the cooled } \\
\text { mash and left to ferment for } \\
\text { overnight. Next morning a frothy } \\
\text { beer is produced, which is filtered } \\
\text { before consumption the same day. }\end{array}$ & $\begin{array}{l}\text { LAB, Saccharomyces } \\
\text { cerevisiae, Candida albidus, } \\
\text { Kluyveromyces marxianus, } \\
\text { Debaryomyces hansenii }\end{array}$ & $\begin{array}{l}\text { Opaque } \\
\text { Alcoholic drink }\end{array}$ & $\begin{array}{l}\text { Cameroon } \\
\text { Chad }\end{array}$ & $\begin{array}{l}\text { Roger et al. } \\
2013 \\
\text { Maoura et al. } \\
2005\end{array}$ \\
\hline Assaliya & $\begin{array}{l}\text { Produced from germinated } \\
\text { sorghum, involves } 40 \text { steps }\end{array}$ & unknown & $\begin{array}{l}\text { Clear sorghum } \\
\text { beer }\end{array}$ & Sudan & \\
\hline Bogobe & $\begin{array}{l}\text { Dehulled sorghum meal is } \\
\text { fermented in water for } 24 \mathrm{~h} \text { using } \\
\text { a starter. The fermented slurry } \\
\text { was then cooked in boiling water } \\
\text { for } 10-12 \text { min to prepare a stiff } \\
\text { porridge }\end{array}$ & $\begin{array}{l}\text { L. reuteri, L. fermentum, } L . \\
\text { harbinensis, L. plantarum, } L . \\
\text { parabuchneri, L. casei and } L . \\
\text { coryniformis }\end{array}$ & $\begin{array}{l}\text { Semi-stiff } \\
\text { porridge taken in } \\
\text { lunch }\end{array}$ & Botswana & $\begin{array}{l}\text { Boling \& } \\
\text { Eisener, } 1982 \\
\text { Monang \& } \\
\text { Gänzle, } 2011\end{array}$ \\
\hline Boza & $\begin{array}{l}\text { Boza Various (barley, oats, } \\
\text { rye, millet, maize, wheat or rice) }\end{array}$ & $\begin{array}{l}\text { LAB: Leuconostoc (Leu. } \\
\text { paramesenteroides, Leu. } \\
\text { sanfranciscensis, Leu. } \\
\text { mesenteroides), Lactobacillus } \\
\text { (Lb. plantarum, Lb. } \\
\text { acidophilus, Lb. fermentum); } \\
\text { Yeast: Saccharomyces (S. } \\
\text { uvarum, S. cerevisiae), Pichia } \\
\text { fermentans, Candida spp. }\end{array}$ & Alcoholic drink & $\begin{array}{l}\text { Kazakhstan, } \\
\text { Turkey, } \\
\text { Kyrgyzstan, } \\
\text { Albania, } \\
\text { Bulgaria, } \\
\text { Macedonia, } \\
\text { Montenegro, } \\
\text { Romania, } \\
\text { Serbia, Bosnia } \\
\text { and } \\
\text { Herzegovina, }\end{array}$ & $\begin{array}{l}\text { Marsh et al. } \\
2014\end{array}$ \\
\hline $\begin{array}{l}\text { Burukutu / } \\
\text { otika }\end{array}$ & $\begin{array}{l}\text { Burukutu production involves } \\
\text { malting, mashing, addition of an } \\
\text { adjunct, fermentation of sorghum } \\
\text { using an old brew as a starter } \\
\text { culture for } 48 \mathrm{~h} \text {; pasteurization } \\
\text { by boiling and maturation. }\end{array}$ & $\begin{array}{l}\text { Saccharomyces cerevisiae, } S . \\
\text { chavelieria and Leuconostoc } \\
\text { mesteroides }\end{array}$ & $\begin{array}{l}\text { Alcoholic } \\
\text { beverage }\end{array}$ & $\begin{array}{l}\text { Nigeria, Benin, } \\
\text { Ghana }\end{array}$ & $\begin{array}{l}\text { Kolawole et al. } \\
2007\end{array}$ \\
\hline
\end{tabular}




\begin{tabular}{|c|c|c|c|c|c|}
\hline Bushera & $\begin{array}{l}\text { Bushera is prepared by cooking } \\
\text { germinated sorghum flour in }(1: 3) \\
\text { water for } 2-5 \text { minutes. After } \\
\text { cooling down, the slurry is added } \\
\text { with sorghum malt to initiate } \\
\text { fermentation. Fermentation is } \\
\text { carried out ambient temperature } \\
\text { for } 1 \text { for production of sweet } \\
\text { bushera and } 2-4 \text { days for sour } \\
\text { bushera }\end{array}$ & & $\begin{array}{l}\text { Sweet bushera as } \\
\text { weaning food and } \\
\text { sour bushera for } \\
\text { older people as } \\
\text { alcoholic } \\
\text { beverage }\end{array}$ & Uganda & $\begin{array}{l}\text { Muyanja et al. } \\
2003\end{array}$ \\
\hline $\begin{array}{l}\text { Chibuku/ } \\
\text { doro, } \\
\text { hwahwa, } \\
\text { mhamba, } \\
\text { rutshwala }\end{array}$ & $\begin{array}{l}\text { Chibuku is prepared by blending } \\
\text { sorghum meal and sorghum malt } \\
\text { with water and lactic acid, which } \\
\text { is gelatinized, mashed and } \\
\text { strained. The solution is malted } \\
\text { and fermentation with yeast to } \\
\text { produce ethanol and carbon } \\
\text { dioxide }\end{array}$ & $\begin{array}{l}\text { Lactobacillus plantarum, Lb. } \\
\text { delbrueckii Lactococcus lactis } \\
\text { lactis, Lc. raffinolactis } \\
\text { Leuconostoc mesenteroides, } \\
\text { Streptococcus, Enterococcus. } \\
\text { S. cerevisiae }\end{array}$ & $\begin{array}{l}\text { Opaque Sorghum } \\
\text { beer }\end{array}$ & $\begin{array}{l}\text { Botswana } \\
\text { Zimbabwe }\end{array}$ & $\begin{array}{l}\text { Togo et al. } \\
2002 \\
\text { Kutyauripo, et } \\
\text { al. } 2009\end{array}$ \\
\hline Chikokivana & $\begin{array}{l}\text { Chikokivana is a 1-day brew } \\
\text { produced from sorghum meal and } \\
\text { malt with water using a yeast as } \\
\text { starter culture }\end{array}$ & Saccharomyces cerevisiae & $\begin{array}{l}\text { Alcoholic } \\
\text { beverage }\end{array}$ & Zimbabwe & $\begin{array}{l}\text { Gadaga et al. } \\
1999\end{array}$ \\
\hline Dolo & & & & Burkina faso & \\
\hline Doro & $\begin{array}{l}\text { Doro is prepared by blending } \\
\text { porridge prepared from sorghum } \\
\text { meal with malt meal and left to } \\
\text { ferment for a few days. The } \\
\text { slurry is then boiled followed by } \\
\text { malt addition. The brew is } \\
\text { fermented for few more days, } \\
\text { followed by boiling, cooling down } \\
\text { to room temperature and } \\
\text { addition of coarsely ground malt. } \\
\text { The mixture is filtered and left to } \\
\text { mature overnight before } \\
\text { consumption }\end{array}$ & $\begin{array}{l}\text { Lactobacillus plantarum, Lb. } \\
\text { delbrueckii Lactococcus lactis } \\
\text { lactis, Lc. raffinolactis } \\
\text { Leuconostoc mesenteroides, } \\
\text { Streptococcus, Enterococcus. } \\
\text { S. cerevisiae }\end{array}$ & $\begin{array}{l}\text { Opaque Sorghum } \\
\text { beer }\end{array}$ & $\begin{array}{l}\text { Botswana } \\
\text { Zimbabwe }\end{array}$ & $\begin{array}{l}\text { Gadaga et al. } \\
1999\end{array}$ \\
\hline Gowe & $\begin{array}{l}\text { Dough prepared from malted } \\
\text { sorghum flour is fermented for } 12 \\
\mathrm{~h} \text { and mixed with unmalted } \\
\text { sorghum flour slurry, which is } \\
\text { then left to ferment for } 12-24 \mathrm{~h}\end{array}$ & $\begin{array}{l}\text { LAB: Lactobacillus } \\
\text { fermentum, Weissella confusa, } \\
\text { Lactobacillus mucosae, } \\
\text { Pediococcus acidilactici, } \\
\text { Pediococcus pentosaceus and } \\
\text { Weissella kimchi } \\
\text { Yeast: Kluyveromyces } \\
\text { marxianus, Pichia anomala, } \\
\text { Candida krusei and Candida } \\
\text { tropicalis }\end{array}$ & $\begin{array}{l}\text { Alcoholic } \\
\text { Beverage }\end{array}$ & $\begin{array}{l}\text { Nigeria } \\
\text { Benin }\end{array}$ & $\begin{array}{l}\text { Vieira-Dalodé } \\
\text { et al. } 2007\end{array}$ \\
\hline Hulu Mur & $\begin{array}{l}\text { Hulu mur is a fermented food } \\
\text { product made from fermented } \\
\text { Sorghum bicolor flour, } \\
\text { Tamarindus indica L, Phoenix } \\
\text { dactylifera, Hibiscus sabdriffa and } \\
\text { spices. Equal proportion of } \\
\text { sorghum malt and porridge made } \\
\text { from sorghum flour mixed and }\end{array}$ & $\begin{array}{l}\text { Saccharomyces } \\
\text { Candida }\end{array}$ & $\begin{array}{l}\text { Fermented non- } \\
\text { alcoholic } \\
\text { beverage }\end{array}$ & Sudan & $\begin{array}{l}\text { Agab, } 1985 \\
\text { Sulieman \& } \\
\text { Abdelgadir } \\
2015\end{array}$ \\
\hline
\end{tabular}




\begin{tabular}{|c|c|c|c|c|c|}
\hline & $\begin{array}{l}\text { left to ferment in sun. During } \\
\text { fermentation spices and date } \\
\text { slurry is added and left to } \\
\text { ferment for } 24-36 \text { h. The dough is } \\
\text { then baked to thick brown sheets, } \\
\text { and to prepare the hulu mur } \\
\text { drink, the sheets are broken into } \\
\text { small pieces and soaked in water } \\
\text { and then strained. }\end{array}$ & & & & \\
\hline Hussuwa & $\begin{array}{l}\text { Hussuwa production involves } \\
\text { cooking of sorghum paste to } \\
\text { produce stiff 'aceda' porridge. To } \\
\text { this, sorghum malt is added and } \\
\text { left to ferment for up to } 48 \text { h, to } \\
\text { give the sourdough called 'ajin' } \\
\text { which is cooked until all moisture } \\
\text { is expelled. After cooking, the } \\
\text { slurry is fermented in an } \\
\text { earthenware pot which is buried } \\
\text { under the fireplace for up to two } \\
\text { months. The cooking of daily } \\
\text { meals over it ensures a } \\
\text { continuous warming throughout } \\
\text { this period of fermentation. }\end{array}$ & $\begin{array}{l}\text { Both lactic acid and ethanolic } \\
\text { fermentation takes place } \\
\text { involving mainly Lactobacillus } \\
\text { fermentum, Pediococcus } \\
\text { acidilactici P. pentosaceus }\end{array}$ & $\begin{array}{l}\text { semi-solid, } \\
\text { dough-like } \\
\text { sweet- } \\
\text { sour fermented } \\
\text { food }\end{array}$ & Sudan & $\begin{array}{l}\text { Yousif et al. } \\
2010\end{array}$ \\
\hline Injera & $\begin{array}{l}\text { Injera, is a large circular, } \\
\text { fermented pancake-like bread. } \\
\text { Dehulled and milled sorghum } \\
\text { flour was mixed with water } \\
\text { (50:50) and the starter, which is } \\
\text { then fermented for } 72 \mathrm{~h} \text {. A portion } \\
\text { of the dough, about } 5 \% \text {, is mixed } \\
\text { with water. This slurry is added } \\
\text { and cooked to make a gruel, } \\
\text { which is then added to the } \\
\text { dough. A batter is formed by } \\
\text { addition of more water; the } \\
\text { batter thus formed is then let to } \\
\text { stand for 2-3 h, and then baked } \\
\text { for 2-3 min in covered condition } \\
\text { to produce injera, a thin spongy } \\
\text { bread }\end{array}$ & Candida guilliermondii & Staple-bread & $\begin{array}{l}\text { Ethiopia, } \\
\text { Eritrea }\end{array}$ & \begin{tabular}{|l} 
Gebrekidan \& \\
Gebrehiwot \\
(1981); \\
Taylor, 2003
\end{tabular} \\
\hline Khamir & $\begin{array}{l}\text { The bread is prepared by mixing } \\
\text { the sorghum flour with water and } \\
\text { spices (onion, garlic, lemon juice } \\
\text { and fenugreek) in a } 1: 0 \cdot 8(\mathrm{w} / \mathrm{w}) \\
\text { ratio and fermented for } 24 \mathrm{~h} \text { at } \\
30{ }^{\circ} \mathrm{C}\end{array}$ & $\begin{array}{l}\text { Bacteria: Pediococcus } \\
\text { pentosaceus, Lactobacillus } \\
\text { brevis, Lact. lactis subsp. } \\
\text { lactis, Lact. cellobiosus, } \\
\text { Klebsiella oxytoca, Kl. } \\
\text { pneumoniae, Enterobacter } \\
\text { aerogenes, Ent. sakazakii, } \\
\text { Serratia marcescens and Ser. } \\
\text { odourifera), mould: } \\
\text { Penicillium sp, Rhizopus sp, } \\
\text { Aspergillus niger, Alternaria } \\
\text { sp, Fusarium sp. and Mucor } \\
\text { sp.) yeast: Candida }\end{array}$ & Staple bread & Arab countries & Gassem, 1999 \\
\hline
\end{tabular}




\begin{tabular}{|c|c|c|c|c|c|}
\hline & & $\begin{array}{l}\text { parapsilosis, C. orvegnsis and } \\
\text { Rhodotorula glutinis). }\end{array}$ & & & \\
\hline Kisra & $\begin{array}{l}\text { Sorghum mixed with water in a } \\
1: 2(\mathrm{wt} . / \mathrm{vol}) \text { ratio and is } \\
\text { fermented at } 30^{\circ} \mathrm{C} \text { for } 24 \mathrm{~h} \text {. The } \\
\text { dough is then baked for } \\
\text { preparation of bread }\end{array}$ & $\begin{array}{l}\text { Mostly LAB and yeast } \\
\text { Pediococcus pentosaceus, } \\
\text { Lactobacillus confusus, } \\
\text { Lactobacillus brevis, } \\
\text { Lactobacillus sp, Erwinia } \\
\text { ananas, Klebsiella } \\
\text { pneumoniae, and Enterobacter } \\
\text { cloacae), yeasts (Candida } \\
\text { intermedia and Debaryomyces } \\
\text { hansenii), and molds } \\
\text { (Aspergillus sp, Penicillium } \\
\text { sp, Fusarium sp, and } \\
\text { Rhizopus sp }\end{array}$ & Staple bread & Sudan & $\begin{array}{l}\text { Mohammed et } \\
\text { al. } 1991 \\
\text { Hamad et al. } \\
1992\end{array}$ \\
\hline Kwunu-Zaki & $\begin{array}{l}\text { In the preparation of Kanun-zaki, } \\
\text { the sorghum kernels are washed } \\
\text { and dried in the sun, then } \\
\text { coarsely ground in a mortar and } \\
\text { pestle. The flour is then is mixed } \\
\text { with hot water to form a paste } \\
\text { which is spontaneously fermented } \\
\text { for } 1-3 \text { days resulting in a sour } \\
\text { beverage. }\end{array}$ & LAB, yeasts & $\begin{array}{l}\text { Paste used as } \\
\text { breakfast dish }\end{array}$ & Nigeria & $\begin{array}{l}\text { Blandino et al. } \\
2003 \\
\text { Nyanzi, \& } \\
\text { Jooste, } 2012\end{array}$ \\
\hline Mahewu & $\begin{array}{l}\text { Mahewu is prepared blending } \\
\text { malted sorghum flour with non- } \\
\text { malted boiled sorghum paste and } \\
\text { allowed to ferment for } 3 \text { days. }\end{array}$ & $\begin{array}{l}\text { Saccharomyces cerevisiae, } \\
\text { Candida spp. Lactobacillus } \\
\text { delbruckii or L. bulgaricus }\end{array}$ & $\begin{array}{l}\text { Non-alcoholic } \\
\text { beverage }\end{array}$ & $\begin{array}{l}\text { Southern } \\
\text { Africa, } \\
\text { Zimbabwe }\end{array}$ & $\begin{array}{l}\text { Bvochora et } \\
\text { al. } 1999\end{array}$ \\
\hline Mangisi & $\begin{array}{l}\text { Mangisi is a sweet-sour beverage } \\
\text { made from the natural } \\
\text { fermentation of millet mash. It } \\
\text { involves malting, drying, } \\
\text { grounding to flour and mixing of } \\
\text { flour with water, followed by } \\
\text { boiling for } 1-2 \text { h and then cooling } \\
\text { down with addition of water, } \\
\text { which is left to ferment. On } \\
\text { second day more On the second } \\
\text { day more malt flour is added and } \\
\text { the mixture left to ferment until } \\
\text { early on the third day when the } \\
\text { coarse solids are strained off and } \\
\text { the fermenting mixture returned } \\
\text { to the fermentation vessel to } \\
\text { produce mangisi. }\end{array}$ & $\begin{array}{l}\text { mesophilic bacteria, lactic acid } \\
\text { bacteria, yeasts and moulds }\end{array}$ & $\begin{array}{l}\text { Sweet-sour non- } \\
\text { alcoholic drink }\end{array}$ & Zimbabwe & $\begin{array}{l}\text { Gadaga et al. } \\
1999\end{array}$ \\
\hline Merissa & $\begin{array}{l}\text { In the first step, sorghum flour } \\
\text { and water mixed to form a } \\
\text { viscous product which is left to } \\
\text { ferment spontaneously and then } \\
\text { baked to produce surij. After } \\
\text { cooling the surij, water, sorghum } \\
\text { malt and Merissa from previous } \\
\text { production is mixed together and } \\
\text { left to ferment for } 7 \text { days. This }\end{array}$ & LAB and Saccharomyces & $\begin{array}{l}\text { Unclear sorghum } \\
\text { beer }\end{array}$ & Sudan & $\begin{array}{l}\text { Zweytick \& } \\
\text { Berghofer, } \\
2009\end{array}$ \\
\hline
\end{tabular}




\begin{tabular}{|c|c|c|c|c|c|}
\hline & $\begin{array}{l}\text { deboba is fermented for } 7 \mathrm{~h} \text { and } \\
\text { filtered. The filtrate is called } \\
\text { mahoj Merissa and the residue is } \\
\text { added with hot water and the } \\
\text { mixture is filtrated to produce } \\
\text { Dagga Merissa. }\end{array}$ & & & & \\
\hline motogo & $\begin{array}{l}\text { Dehulled sorghum meal is } \\
\text { fermented in warm water for } 24 \mathrm{~h} \\
\text { using a starter. The fermented } \\
\text { slurry was then cooked in boiling } \\
\text { water to prepare a soft porridge }\end{array}$ & lactic acid bacteria and yeasts & $\begin{array}{l}\text { soft porridge } \\
\text { consumed for } \\
\text { breakfast }\end{array}$ & Botswana & $\begin{array}{l}\text { Monang \& } \\
\text { Gänzle, } 2011\end{array}$ \\
\hline Munkoyo & $\begin{array}{l}\text { Munkoyo production involves } \\
\text { cooking the sorghum grain flour } \\
\text { in water, liquefaction- } \\
\text { saccharification of the porridge } \\
\text { gel with munkoyo roots (Eminia, } \\
\text { Rhynchosia and Vigna species), } \\
\text { and fermentation. }\end{array}$ & $\begin{array}{l}\text { LAB: Lactobacillus delbrueckii } \\
\text { subsp. Lactis and yeast }: S . \\
\text { cerevisiae }\end{array}$ & $\begin{array}{l}\text { Slightly alcoholic } \\
\text { beverage }\end{array}$ & $\begin{array}{l}\text { Democratic } \\
\text { Republic of } \\
\text { Congo (D.R.C) } \\
\text { and Zambia }\end{array}$ & $\begin{array}{l}\text { Foma et al. } \\
2012 ; \\
\text { Schoustra et } \\
\text { al. } 2013\end{array}$ \\
\hline Ogi-baba & $\begin{array}{l}\text { Ogi is a smooth, creamy, free- } \\
\text { flowing thin porridge obtained } \\
\text { from wet-milled, sorghum } \\
\text { (Sorghum vulgare). Sorghum } \\
\text { grains are soaked for 1-3 days } \\
\text { and wet milled followed by } \\
\text { sieving to remove bran, hull and } \\
\text { germ. The filtrate is fermented } \\
\text { for } 2-3 \text { days and the wet cake, } \\
\text { ogi-baba is added with water and } \\
\text { boiled to prepare a stiff porridge } \\
\text { (agidi). }\end{array}$ & $\begin{array}{l}\text { Lactobacillus plantarum, } \\
\text { Saccharomyces cerevisiae, } \\
\text { Candida mycoderma, } \\
\text { Corynebacterium, Aerobacter, } \\
\text { Rhodotorula, Cephalosporium, } \\
\text { Fusarium, Aspergillus and } \\
\text { Penicillium, } \\
\text { Debaryomyces hansenii, } \\
\text { Candida krusei, }\end{array}$ & $\begin{array}{l}\text { Paste as staple. } \\
\text { For breakfast } \\
\text { or weaning food } \\
\text { for babies }\end{array}$ & $\begin{array}{l}\text { Nigeria, } \\
\text { West Africa }\end{array}$ & $\begin{array}{l}\text { Blandino et al. } \\
2003 \\
\text { Oyarekua \& } \\
\text { Eleyinmi, } \\
2004 ; \\
\text { Odunfa\& } \\
\text { Adeyele, } 1985\end{array}$ \\
\hline Omuramba & $\begin{array}{l}\text { Soaking of sorghum grains for } \\
12 \mathrm{~h} \text {, addition of ash to increase } \\
\text { the mineral content and allowed } \\
\text { to germinate for } 3 \text { days, washed } \\
\text { and sundried, followed by } \\
\text { grinding to coarse flour. The flour } \\
\text { is added with water and allowed } \\
\text { to stand for } 5-7 \text { days. The } \\
\text { mixture is boiled, cooled left to } \\
\text { stand for another } 2-3 \text { days. Yeast } \\
\text { is added to ferment the mixture } \\
\text { for } 2 \text { days. Whole process takes } \\
\text { about } 4 \text { weeks, with series of } \\
\text { boiling and fermentation process. } \\
\end{array}$ & Yeast & $\begin{array}{l}\text { Alcoholic } \\
\text { beverage }\end{array}$ & Uganda & $\begin{array}{l}\text { Mwesigye \& } \\
\text { Okurut, } 1995\end{array}$ \\
\hline Pito & $\begin{array}{l}\text { The process of pito production } \\
\text { involves malting, mashing, } \\
\text { fermentation and maturation. In } \\
\text { this case different types of grains } \\
\text { are used to brew it and adjunct is } \\
\text { not added. }\end{array}$ & $\begin{array}{l}\text { Geotrichum } \\
\text { candidum and Lactobacillus } \\
\text { species }\end{array}$ & $\begin{array}{l}\text { Alcoholic dark } \\
\text { brown drink }\end{array}$ & Nigeria, Ghana & $\begin{array}{l}\text { Kolawole et al. } \\
2007\end{array}$ \\
\hline Tchapalo & $\begin{array}{l}\text { Tchapalo is prepared from malted } \\
\text { sorghum flour. This flour was } \\
\text { mixed with water containing a } \\
\text { sticky substance from the bark of }\end{array}$ & $\begin{array}{l}\text { L. fermentum, L. cellobiosus, } \\
\text { L. brevis, L. coprophilus, L. } \\
\text { plantarum and Yeast }\end{array}$ & $\begin{array}{l}\text { Opaque sour beer } \\
\text { Alcoholic drink }\end{array}$ & Cote d'Ivoire & $\begin{array}{l}\text { Marcellin et } \\
\text { al. } 2009\end{array}$ \\
\hline
\end{tabular}




\begin{tabular}{|c|c|c|c|c|c|}
\hline & $\begin{array}{l}\text { a shrub (Anogeissus leo carpus). } \\
\text { The mash so obtained is decanted } \\
\text { to separate supernatant and } \\
\text { sediment. The sediment was } \\
\text { cooked, mixed with the } \\
\text { supernatant to give wort, which } \\
\text { is then fermented naturally } \\
\text { overnight to produce sour wort. } \\
\text { The sour wort was cooked, cooled } \\
\text { and inoculated with yeast for } 9 \text { - } \\
12 \text { h to produce tchapalo. }\end{array}$ & & & & \\
\hline Tella & $\begin{array}{l}\text { Unleavened bread (kita) is } \\
\text { prepared from the malt (bikil) of } \\
\text { barley/maize/wheat / sorghum } \\
\text { and broken into pieces. Sorghum } \\
\text { grain is ground to flour and } \\
\text { roasted (enkuro). Dried gesho } \\
\text { leaves are soaked in water for } 4-5 \\
\text { d. The mixture of malt (bikil) } \\
\text { and unleavened bread pieces } \\
\text { (kita) is put into the gesho leaf- } \\
\text { soaked water with additional } \\
\text { powders of gesho leaves and stem } \\
\text { and left to ferment for } 2 \text { days or } \\
\text { more. At the third stage, powder } \\
\text { of the gesho leaves and pounded } \\
\text { stem and cereal flour are mixed } \\
\text { into a thick slurry and left to } \\
\text { ferment for } 2 \text { days or more. At } \\
\text { the final phase, the container is } \\
\text { filled with water to the brim and } \\
\text { the slurry is mixed thoroughly. } \\
\text { The container is then sealed with } \\
\text { mud to create an anaerobic } \\
\text { condition and left for } 2 \text { days or } \\
\text { more. Tella is consumed directly } \\
\text { or after filtration. }\end{array}$ & $\begin{array}{l}\text { Saccharomyces cerevisiae and } \\
\text { Lactobacillus pastorianumi }\end{array}$ & Alcoholic drink & Ethiopia & Lee et al. 2015 \\
\hline Ting & $\begin{array}{l}\text { Spontaneous fermentation is } \\
\text { carried out by mixing sorghum } \\
\text { flour }(40-45 \%) \text { with warm water } \\
(55-60 \%) \text {. The slurry is } \\
\text { fermented in a warm place }(30- \\
\left.37^{\circ} \mathrm{C}\right) \text { for } 2-3 \text { days. } \\
\text { Alternatively, sorghum slurries } \\
\text { are inoculated with material from } \\
\text { a previous fermentation. } \\
\text { Fermentation of slurry is } \\
\text { completed in in } 1-3 \text { days for } \\
\text { production of Ting. }\end{array}$ & $\begin{array}{l}\text { Lactococcus lactis, } \\
\text { Lactobacillus fermentum, L. } \\
\text { plantarum, L. rhamnosus, } \\
\text { Weissella cibaria, } \\
\text { Enterococcus faecalis, L. } \\
\text { curvatus, Enterobacteriacea } \\
\text { L. reuteri, L. fermentum, L. } \\
\text { harbinensis, L. plantarum, L. } \\
\text { parabuchneri, L. casei and L. } \\
\text { coryniformis }\end{array}$ & Sour porridge & $\begin{array}{l}\text { South Africa } \\
\text { Botswana }\end{array}$ & $\begin{array}{l}\text { Madoroba et } \\
\text { a, } 2011 \\
\text { Sekwati- } \\
\text { Monang \& } \\
\text { Gänzle, 2011 }\end{array}$ \\
\hline Togwa & $\begin{array}{l}\text { A slurry prepared from sorghum } \\
\text { or mixture of sorghum-maize } \\
\text { flour is prepared ( } 5-15 \% \mathrm{w} / \mathrm{v}) \text {, } \\
\text { which is boiled for } 15 \mathrm{~min} \text { and } \\
\text { left to cool down. To it malt flour }\end{array}$ & $\begin{array}{l}\text { Lactobacillus brevis, } \\
\text { Lactobacillus cellobiosus, } \\
\text { Lactobacillus fermentum, } \\
\text { Lactobacillus plantarum and } \\
\text { Pediococcus pentosaceus) and }\end{array}$ & $\begin{array}{l}\text { fermented gruel } \\
\text { or beverage } \\
\text { consumed as } \\
\text { weaning food or } \\
\text { beverage after }\end{array}$ & Tanzania & $\begin{array}{l}\text { Mugula et al. } \\
2003 a, b\end{array}$ \\
\hline
\end{tabular}




\begin{tabular}{|c|c|c|c|c|c|}
\hline & $\begin{array}{l}\text { or back slopping is added and } \\
\text { allowed to ferment for } 9-24 \mathrm{~h} \text { at } \\
\text { ambient temperature to produce } \\
\text { Togwa }\end{array}$ & $\begin{array}{l}\text { yeasts (Candida pelliculosa, } \\
\text { Candida tropicalis, } \\
\text { Issatchenkia orientalis, } \\
\text { Saccharomyes cerevisiae } \\
\text { Weissella confusa, }\end{array}$ & dilution & & \\
\hline $\begin{array}{l}\text { Tonto/ } \\
\text { Urwagwa/ } \\
\text { Mbege/ } \\
\text { Urwaga/ } \\
\text { isongo }\end{array}$ & $\begin{array}{l}\text { Ripened green banana juice is } \\
\text { added with roasted and ground } \\
\text { sorghum and fermented for } 2-4 \\
\text { days in warm pits. The alcohol } \\
\text { content is about } 6-11 \% \text {. The } \\
\text { process of ripening bananas, juice } \\
\text { extraction and fermentation of } \\
\text { the final product took about } 9 \text { to } \\
10 \text { days. }\end{array}$ & $\begin{array}{l}\text { Lactic acid bacteria, yeast and } \\
\text { molds and aerobic mesophilic } \\
\text { bacteria }\end{array}$ & $\begin{array}{l}\text { Banana beer: } \\
\text { alcoholic drink }\end{array}$ & $\begin{array}{l}\text { Uganda } \\
\text { Rwanda } \\
\text { Tanzania } \\
\text { Kenya } \\
\text { Burundi }\end{array}$ & $\begin{array}{l}\text { Mwesigye \& } \\
\text { Okurut, 1995; } \\
\text { Wilson et al. } \\
(2012)\end{array}$ \\
\hline Uji & $\begin{array}{l}\text { Mixture of maize and sorghum } \\
\text { flour is slurried with water and } \\
\text { allowed to ferment for 1-3 days, } \\
\text { diluted to desired consistency } \\
\text { followed by boiling and sweetened } \\
\text { with sugar. }\end{array}$ & $\begin{array}{l}\text { Lb. plantarum, Lb. } \\
\text { fermentum, Lb. cellobiosus } \\
\text { and Lb. buchneri, Pediococcus } \\
\text { acidilactici and } P . \\
\text { pentosaceus }\end{array}$ & $\begin{array}{l}\text { Porridge: } \\
\text { Hot form as } \\
\text { breakfast, cold } \\
\text { form as thirst } \\
\text { quenching and } \\
\text { light midday } \\
\text { meal }\end{array}$ & $\begin{array}{l}\text { Est Africa, } \\
\text { Kenya, Uganda, } \\
\text { Tanganyika }\end{array}$ & $\begin{array}{l}\text { Masha et al. } \\
\text { 1998; Nyanzi, } \\
\text { \& Jooste, } 2012\end{array}$ \\
\hline
\end{tabular}

\section{References}

1. Abdel-Rahman IE and Osman MAW (2011). Effect of sorghum type (Sorghum bicolor) and traditional fermentation on tannins and phytic acid contents and trypsin inhibitor activity. Food, Agriculture \& Environment, 9:163-166.

2. Abdelseed BH, Abdalla AH, Yagoub AEGA, El-Gasim A, Mohamed Ahmed IA and Babiker EE (2011). Some nutritional attributes of selected newly developed lines of sorghum (Sorghum bicolor) after fermentation. Journal of Agricultural Science and Technology, 13, 399-409.

3. Adams MR and Nicolaides L (1997). Review of the sensitivity of different foodborne pathogens to fermentation. Food Control, 8(5), 227-239.

4. Afify AEMMR, El-Beltagi HS, Abd El-Salam SM and Omran AA (2011). Bioavailability of iron, zinc, phytate and phytase activity during soaking and germination of white sorghum varieties. PLoS ONE, 6:255-212.

5. Afify AEMMR, El-Beltagi HS, El-Salam SMA and Omran AA (2012). Biochemical changes in phenols, flavonoids, tannins, vitamin E, $\beta$-carotene and antioxidant activity during soaking of three white sorghum varieties. Asian Pacific Journal of Tropical Biomedicine, 2:203-209.

6. Agab MA (1985). Fermented food products 'Hulu Mur'drink made from Sorghum bicolor. Food Microbiology, $2(2), 147-155$.

7. Al-Mamary M, Al-habori M, Al-Aghbari A, Al-Obeidi A (2001). In vivo effects of dietary sorghum tannins on rabbit digestive enzymes and mineral absorption. Nutrition Research, 21, 1393-1401.

8. Asha K, Geetha VB, Sheela K and Dhanapal GN (2005). Nutritional Composition of Sorghum and Moth Bean Incorporated Traditional Recipies. Journal of Human Ecology, 17(3), 201-203.

9. Awika JM and Rooney LW (2004). Sorghum phytochemicals and their potential impact on human health. Phytochemistry, 65(9), 1199-1221.

10.Axtell JD, Kirleis AW, Hassen MM, Mason NDC, Mertz ET and Munck L (1981). Digestibility of sorghum proteins. Proceedings of the National Academy of Sciences, 78(3), 1333-1335.

11.Barros F, Awika JM and Rooney LW (2012). Interaction of tannins and other sorghum phenolic compounds with starch and effects on in vitro starch digestibility. Journal of Agricultural and Food Chemistry, 60(46), 1160911617 .

12.Benmoussa M, Suhendra B, Aboubacar A and Hamaker BR (2006). Distinctive sorghum starch granule morphologies appear to improve raw starch digestibility. Starch-Stärke, 58(2), 92-99. 
13.Blandino A, Al-Aseeri ME, Pandiella SS, Cantero D and Webb C (2003). Cereal-based fermented foods and beverages. Food Research International, 36(6), 527-543.

14.Boling MB and Eisener N (1982). Bogobe: sorghum porridge of Botswana. In International Crops Research Institute for the Semi-Arid Tropics: Proceedings of the International Symposium on Sorghum Grain Quality, Patancheru (pp. 32-35).

15.Brohan M, Jerkovic V and Collin S (2011). Potentiality of red sorghum for producing stilbenoid-enriched beers with high antioxidant activity. Journal of Agricultural and Food Chemistry, 59:4088-4094.

16.Bvochora JM, Reed, JD, Read, JS and Zvauya R (1999). Effect of fermentation processes on proanthocyanidins in sorghum during preparation of Mahewu, a non-alcoholic beverage. Process Biochemistry, 35(1), 21-25.

17. Chavan UD, Chavan JK and Kadam SS (1988a). Effect of fermentation on soluble proteins and in vitro protein digestibility of sorghum, green gram and sorghum-green gram blends. Journal of Food Science, 53(5), 1574-1575.

18.Chigumira, P (1992). The potential for extruded sorghum food products in Zimbabwe and the regional market. Pages 89-94.

19.Chong J, Poutaraud A and Hugueney P (2009). Metabolism and roles of stilbenes in plants. Plant Science 177:143-155.

20.Chung IM, Yong SJ, Lee J and Kim SH (2013). Effect of genotype and cultivation location on $\beta$-sitosterol and $\alpha-$, $\beta-$, Y-, and $\delta$-tocopherols in sorghum. Food Research International, 51:971-976.

21.Cruzy Celis LP, Rooney LW and McDonough CM (1996). A ready-to-eat breakfast cereal from food-grade sorghum. Cereal Chemistry, 73(1), 108-114.

22.D'Archivio M, Filesi C, Varì R, Scazzocchio B and Masella R ( $\beta 010)$. Bioavailability of the polyphenols: status and controversies. International Journal of Molecular Sciences, 11:1321-1342.

23.De Wet JMJ and Huckabay JP (1967). The origin of Sorghum bicolor. II. Distribution and domestication. Evolution, 21(4), 787-802.

24.Desikachar HSR (1975). Processing of maize, sorghum and millets for food uses. Journal of Scientific and Industrial Research, 34:231-6

25.Dharmaraj U and Malleshi NG (2011). Changes in carbohydrates, proteins and lipids of finger millet after hydrothermal processing. LWT-Food Science and Technology, 44(7), 1636-1642.

26. Dicko MH, Gruppen H, Barro C, Traore AS, van Berkel WJ and Voragen AG (2005). Impact of phenolic compounds and related enzymes in sorghum varieties for resistance and susceptibility to biotic and abiotic stresses. Journal of Chemical Ecology, 31:2671-2688.

27.Dicko MH, Gruppen H, Traoré AS, Voragen AG and van Berkel WJ (2006). Review: sorghum grain as human food in Africa: relevance of starch content and amylase activities. African Journal of Biotechnology, 5, 384-395.

28.Duodu KG, Taylor JRN, Belton PS and Hamaker BR (2003). Factors affecting sorghum protein digestibility. Journal of Cereal Science, 38(2), 117-131.

29.Dykes L and Rooney LW (2006). Sorghum and millet phenols and antioxidants. Journal of Cereal Science, 44:236-251.

30.Dykes, L, Peterson, G. C, Rooney, W. L and Rooney, L. W (2011).Flavonoid composition of lemon-yellow sorghum genotypes. Food Chemistry, 128:173-179.

31.Dykes, L, Rooney, L. W, Waniska, R. D and Rooney, W. L (2005). Phenolic compounds and antioxidant activity of sorghum grains of varying genotypes. Journal of agricultural and food chemistry 53:6813-6818.

32.El Khalifa AEO, Schiffler B and Bernhard R (2004). Effect of fermentation on the starch digestibility, resistant starch and some physicochemical properties of sorghum flour. Food/Nahrung, 48(2), 91-94.

33.El Khalifa AEO, Schiffler B and Bernhardt R (2005). Effect of fermentation on the functional properties of sorghum flour. Food Chemistry, 92(1), 1-5.

34.El Khalifa AO and El Tinay AH (1994). Effect of fermentation on protein fractions and tannin content of lowand high-tannin cultivars of sorghum. Food Chemistry, 49(3), 265-269.

35.ELKhier MKS and Abd-Al Raheem AA (2011). Effect of fermentation period on the chemical composition, in vitro protein digestibility and tannin content in two Sorghum cultivars (Dabar and Tabat) in Sudan. Journal of Applied Bioscience, 39, 2602-2606.

36.Eller MS, Ostrom K, Gilchrest BA (1996). DNA damage enhances melanogenesis. Proceedings of the National Academy of Sciences of the United States of America 93, 1087-1092. 
37.Faria A, Fernandes I, Mateus N and Calhau C (2013). Bioavailability of Anthocyanins. In: Natural Products, pp. 2465-2487. K. G. Ramawat \& J.-M. Mérillon Eds, Springer Berlin Heidelberg,

38. Floegel A, Kim DO, Chung SJ, Song WO, Fernandez ML, Bruno RS, Koo SI and Chun OK (2010). Development and validation of an algorithm to establish a total antioxidant capacity database of the US diet. International Journal of Food Sciences and Nutrition, 61:600-623

39.Foma RK, Destain J, Mobinzo PK, Kayisu K and Thonart P (2012). Study of physicochemical parameters and spontaneous fermentation during traditional production of munkoyo, an indigenous beverage produced in Democratic Republic of Congo. Food Control, 25(1), 334-341.

40.Fombang EN, Taylor JRN, Mbofung CMF and Minnaar A (2005). Use of $\gamma$-irradiation to alleviate the poor protein digestibility of sorghum porridge. Food Chemistry, 91(4), 695-703.

41.Gadaga TH, Mutukumira AN, Narvhus JA and Feresu SB (1999). A review of traditional fermented foods and beverages of Zimbabwe. International Journal of Food Microbiology, 53(1), 1-11.

42.Gassem MAA (1999). Study of the micro-organisms associated with the fermented bread (khamir) produced from sorghum in Gizan region, Saudi Arabia. Journal of Applied Microbiology, 86(2), 221-225.

43.Gebrekidan B and Gebrehiwot B (1981). Sorghum injera preparations and quality parameters. In Proceedings of the International Symposium on Sorghum Grain Quality, 21-31 October (pp. 55-65).

44.Gibson GR and Wang X (1994). Regulatory effects of bifidobacteria on the growth of other colonic bacteria. Journal of Applied Bacteriology, 77(4), 412-420.

45.Gomez MI, House LR, Rooney LW and Dendy DAV. Utilization of sorghum and millets (eds,). Patancheru, A.P. 502 324, India: International Crops Research Institute for the Semi-Arid Tropics.

46.Gomez-Cordovez Bartolomez B, Vieira W, Viradir VM (2001). Effects of wine phenolics and sorghum tannins on tyrosinase activity and growth of melanoma cells. Journal of Agricultural and Food Chemistry, 49, 1620-1624.

47.Grimmer HR, Parbhoo V, McGarth RM (1992). Antimutagenicity of polyphenol-rich fractions from Sorghum bicolor grain. Journal of Agricultural and Food Chemistry, 59, 251-256.

48.Hagerman AE and Butler LG (1981). The specificity of proanthocyanidin- protein interactions. Journal of Biological Chemistry, 256, 4494-4497.

49.Hahn D and Rooney L (1986). Effect of genotype on tannins and phenols of sorghum. Cereal Chemistry, 63:4-8.

50.Hamad SH, Böcker G, Vogel RF and Hammes WP (1992). Microbiological and chemical analysis of fermented sorghum dough for Kisra production. Applied Microbiology and Biotechnology, 37(6), 728-731.

51.Hamaker BR, Kirleis AW, Butler LG, Axtell JD and Mertz ET (1987). Improving the in vitro protein digestibility of sorghum with reducing agents. Proceedings of the National Academy of Sciences, 84(3), 626-628.

52.Hamaker BR, Kirleis AW, Mertz ET and Axtell JD (1986). Effect of cooking on the protein profiles and in vitro digestibility of sorghum and maize. Journal of Agricultural and Food Chemistry, 34(4), 647-649.

53.Hassan IA and El Tinay AH (1995). Effect of fermentation on tannin content and in-vitro protein and starch digestibilities of two sorghum cultivars. Food Chemistry, 53(2), 149-151.

54.Heinemann RJB, Fagundes PL, Pinto EA, Penteado MVC and Lanfer-Marquez UM (2005). Comparative study of nutrient composition of commercial brown, parboiled and milled rice from Brazil. Journal of Food Composition and Analysis, 18, 4: 287-296.

55.Hesseltine CW (1979). Some important fermented foods of Mid-Asia, the Middle East, and Africa. Journal of the American Oil Chemists' Society, 56(3), 367-374.

56.Hinman DD and Johnson RR (1974). Influence of processing methods on digestion of sorghum starch in high concentrate beef cattle rations. Journal of Animal Science, 39(2), 417-422.

57.Hole AS, Rud I, Grimmer S, Sigl S, Narvhus J and Sahlstrøm S(2012). Improved bioavailability of dietary phenolic acids in whole grain barley and oat groat following fermentation with probiotic Lactobacillus acidophilus, Lactobacillus johnsonii, and Lactobacillus reuteri. Journal of Agricultural and Food Chemistry, 60:6369-6375.

58.Hurrell RF, Reddy MB, Juillerat MA and Cook JD (2003). Degradation of phytic acid in cereal porridges improves iron absorption by human subjects. The American Journal of Clinical Nutrition, 77(5), 1213-1219.

59.Ibrahim FS, Babiker EE, Yousif NE and El-Tinay AH (2005). Effect of whey protein supplementation and/or fermentation on biochemical and sensory characteristics of sorghum flour. Journal of Food Technology, 3(2), 118125. 
60.Idris WH, Hassan AB, Babiker EE and El Tinay AH (2005). Effect of malt pretreatment on antinutritional factors and $\mathrm{HCl}$ extractatibility of minerals of sorghum cultivars. Pakistan Journal of Nutrition, 4(6), 396-401.

61.Jahan A, Rani U, Aparna K and Banu N (2013). Comparison between glycemic index and in-vitro carbohydrate digestibility in IDLI using rice rawa vs jowar rawa. The Journal of Research ANGRAU, 41(4), 93-96

62.Kamath VG, Chandrashekar A and Rajini PS (2004). Antiradical properties of sorghum (Sorghum bicolor L. Moench) flour extracts. Journal of Cereal Science, 40(3), 283-288.

63.Kaufman RC, Herald TJ, Bean SR, Wilson JD and Tuinstra MR (2013). Variability in tannin content, chemistry and activity in a diverse group of tannin containing sorghum cultivars. Journal of the Science of Food and Agriculture, 93:1233-1241.

64.Kazanas N and Fields ML (1981). Nutritional improvement of sorghum by fermentation. Journal of Food Science, $46(3), 819-821$.

65.Kingamkono R, Sjögren E and Svanberg U (1999). Enteropathogenic bacteria in faecal swabs of young children fed on lactic acid-fermented cereal gruels. Epidemiology and Infection, 122(01), 23-32.

66.Kingamkono R, Sjögren E, Svanberg U and Kaijser B (1994). pH and acidity in lactic-fermenting cereal gruels: effects on viability of enteropathogenic microorganisms. World Journal of Microbiology and Biotechnology, 10(6), 664-669.

67.Kingamkono R, Sjögren E, Svanberg U and Kaijser B (1995). Inhibition of different strains of enteropathogens in a lactic-fermenting cereal gruel. World Journal of Microbiology and Biotechnology, 11(3), 299-303.

68.Kobue-Lekalake RI, Taylor J and De Kock HL (2007). Effects of phenolics in sorghum grain on its bitterness, astringency and other sensory properties. Journal of the Science of Food and Agriculture, 87(10), 1940-1948.

69.Kolawole OM, Kayode RMO and Akinduyo B (2007). Proximate and microbial analyses of burukutu and pito produced in Ilorin, Nigeria. African Journal of Biotechnology, 6(5), 587.

70.Krishnamoorthy S, Kunjithapatham S and Manickam L (2013). Traditional Indian breakfast (Idli and Dosa) with enhanced nutritional content using millets. Nutrition and Dietetics, 70(3), 241-246.

71.Krueger CG, Vestling MA and Reed JD (2003). Matrix-assisted laser desorption/ionization time-of-flight mass spectrometry of heteropolyflavan-3-ols and glucosylated heteropolyflavans in sorghum (Sorghum bicolor (L.) Moench). Journal of Agricultural and Food Chemistry, 51, 538-543.

72.Kruger J, Taylor JR and Oelofse A (2012). Effects of reducing phytate content in sorghum through genetic modification and fermentation on in vitro iron availability in whole grain porridges. Food Chemistry, 131(1), $220-224$.

73.Kutyauripo J, Parawira W, Tinofa S, Kudita I and Ndengu C (2009). Investigation of shelf-life extension of sorghum beer (Chibuku) by removing the second conversion of malt. International Journal of Food Microbiology, $129(3), 271-276$.

74.Laetitia MM, Joseph HD, Joseph D and Christian M (2005). Physical, chemical and microbiological changes during natural fermentation of" gowé", a sprouted or non-sprouted sorghum beverage from West-Africa. African Journal of Biotechnology, 4(6), 487.

75.Laetitia MM, Joseph HD, Joseph D and Christian M (2005). Physical, chemical and microbiological changes during natural fermentation of" gowé", a sprouted or non-sprouted sorghum beverage from West-Africa. African Journal of Biotechnology, 4(6), 487.

76.Lee M, Regu M and Seleshe S (2015). Uniqueness of Ethiopian traditional alcoholic beverage of plant origin, tella. Journal of Ethnic Foods, 2(3), 110-114.

77.Lee SM and Pan BS (2003). Effects of dietary sorghum distillery residue on hematological characteristics of cultured grey mullet (Mugil cephalus) - an animal model for prescreening antioxidant and blood thinning activities. Journal of Food Biochemistry, 27, 1-18.

78.Lyimo JMM (2000). Evaluation of the nutritional quality and acceptability of sorghum-based tempe as potential weaning foods in Tanzania. International Journal of Food Sciences and Nutrition, 51(4), 269-277.

79.MacLean Jr WC, López DRG, Gastañaduy A and Graham GG (1983). The effect of decortication and extrusion on the digestibility of sorghum by preschool children. The Journal of Nutrition, 113(10), 2071-2077.

80.Madoroba E, Steenkamp ET, Theron J, Scheirlinck I, Cloete TE and Huys G (2011). Diversity and dynamics of bacterial populations during spontaneous sorghum fermentations used to produce ting, a South African food. Systematic and Applied Microbiology, 34(3), 227-234. 
81. Mahasukhonthachat K, Sopade PA and Gidley MJ (2010). Kinetics of starch digestion and functional properties of twin-screw extruded sorghum. Journal of Cereal Science, 51(3), 392-401.

82.Makokha AO, Oniang'o RK, Njoroge SM and Kamar OK (2002). Effect of traditional fermentation and malting on phytic acid and mineral availability from sorghum (Sorghum bicolor) and finger millet (Eleusine coracana) grain varieties grown in Kenya. Food and Nutrition Bulletin, 23(3 Suppl), 241-245.

83. Maoura N, Mbaiguinam M, Nguyen HV, Gaillardin C and Pourquie J (2005). Identification and typing of the yeast strains isolated from bili bili, a traditional sorghum beer of Chad. African Journal of Biotechnology, 4(7), 646-656.

84.Marcellin, DJE, Solange AKA, Zinzendorf NY, Kouadio YAO and Guillaume, LY (2009). Predominant lactic acid bacteria involved in the spontaneous fermentation step of tchapalo process, a traditional sorghum beer of Côte d'Ivoire. Research Journal of Biological Sciences, 4(7), 789-795.

85.Marsh AJ, Hill C, Ross RP and Cotter PD (2014). Fermented beverages with health-promoting potential: the past and future perspectives. Trends in Food Science and Technology, 38(2), 113-124.

86. Masha GGK, Ipsen R, Petersen MA and Jakobsen M (1998). Microbiological, rheological and aromatic characteristics of fermented Uji (an East African Sour Porridge). World Journal of Microbiology and Biotechnology, 14(3), 451-456.

87.Mohammed SI, Steenson LR and Kirleis AW (1991). Isolation and characterization of microorganisms associated with the traditional sorghum fermentation for production of Sudanese kisra. Applied and Environmental Microbiology, 57(9), 2529-2533.

88. Moongngarm A and Saetung N (2010). Comparison of chemical compositions and bioactive compounds of germinated rough rice and brown rice. Food Chemistry, 122(3), 782-788.

89. Moreau RA, Powell MJ and Hicks KB (1996). Extraction and quantitative analysis of oil from commercial corn. Journal of Agricultural and Food Chemistry, 44, 2149-2154.

90.Mugula JK, Narvhus JA and Sørhaug T (2003a). Use of starter cultures of lactic acid bacteria and yeasts in the preparation of togwa, a Tanzanian fermented food. International Journal of Food Microbiology, 83(3), 307-318.

91.Mugula JK, Nnko SAM, Narvhus JA and Sørhaug T (2003b). Microbiological and fermentation characteristics of togwa, a Tanzanian fermented food International Journal of Food Microbiology, 80(3), 187-199.

92.Muyanja CMBK, Kikafunda JK, Narvhus JA, Helgetun K and Langsrud T (2003). Production methods and composition of Bushera: a Ugandan traditional fermented cereal beverage. African Journal of Food, Agriculture, Nutrition and Development, 3(1), 10-19.

93.Mwesigye PK and Okurut TO (1995). A survey of the production and consumption of traditional alcoholic beverages in Uganda. Process Biochemistry, 30(6), 497-501.

94.Naczk M and Shahidi F (1997). Nutritional implications of canola condensed tannins. Antinutrients and Chemicals in Food: ACS Symposium Series 662, 186-208.

95.Nazni P and Shalini S (2010). Physical and Nutritional evaluation of idli prepared from sorghum (sorghum bicolor 1. moench). Asian Journal of Science and Technology, 2, 44-48.

96.Nyanzi R and Jooste PJ (2012). Cereal-based functional foods. INTECH Open Access Publisher.

97.Odunfa SA and Adeyele S (1985). Microbiological changes during the traditional production of ogi-baba, a West African fermented sorghum gruel. Journal of Cereal Science, 3(2), 173-180.

98. Osman MA (2004). Changes in sorghum enzyme inhibitors, phytic acid, tannins and in vitro protein digestibility occurring during Khamir (local bread) fermentation. Food Chemistry, 88(1), 129-134.

99. Oyarekua MA and Eleyinmi AF (2004). Comparative evaluation of the nutritional quality of corn, sorghum and millet ogi prepared by a modified traditional technique. Journal of Food Agriculture and Environment, 2, 94-99.

100. Oyewole OB (1997). Lactic fermented foods in Africa and their benefits. Food Control, 8(5), 289-297.

101.Pawar VD and Parlikar GS (1990). Reducing the polyphenols and phytate and improving the protein quality of pearl millet by dehulling and soaking. Journal of Food Science and Technology, 27(3):140-143.

102.Ragaee S, Abdel-Aal ESM and Noaman M (2006). Antioxidant activity and nutrient composition of selected cereals for food use. Food Chemistry, 98(1), 32-38.

103.Raghavendra SN, Malleshi NG, Sreedhara Murthy S, Viraktamath CS and Desikachar HSR (1979). Characteristics of roti, dosa and vermicilli from maize, sorghum and bajra. Journal of Food Science and Technology, (16), 21-24. 
104.Raimi O, Olaitan S, Fajana O and Sanni J (2012). Effect of germination time on fat and protein contents, and $\alpha$-amylase activity of Guinea Corn (Sorghum vulgare). Pakistan Journal of Food Sciences, 22:86-89.

105.Rao SA, Rao KP, Mengesha MH and Reddy VG (1996). Morphological diversity in sorghum germplasm from India. Genetic Resources and Crop Evolution, 43(6), 559-567.

106.Reddy G, Altaf MD, Naveena BJ, Venkateshwar M and Kumar EV (2008). Amylolytic bacterial lactic acid fermentation - a review. Biotechnology Advances, 26(1), 22-34.

107.Roger D, Venassius L, Justin ENJ and Xavier EF (2013). Processing of "Amgba": A sorghum-maize based beer, brewed in Cameroon. Journal of Brewing and Distilling, 4(1), 11-18.

108.Rohrbach DD and Obilana AB (2004). The commercialization of sorghum and pearl millet in Africa: traditional and alternative foods, products and industrial uses in perspective. In: Alternative Uses of Sorghum and Pearl Millet in Asia: Proceedings of the Expert Meeting; 2003 July 1-4. Patancheru, Andhra Pradesh, India: ICRISAT. CFC Technical Paper Nr 34. 233-63.

109.Rooney LW (2015). The Utilization of Sorghum: A World Review. REVISTA CEIBA, 29(2), 191-203.

110.Rooney LW and Pflugfelder RL (1986). Factors affecting starch digestibility with special emphasis on sorghum and corn. Journal of Animal Science, 63(5), 1607-1623.

111.Sandberg AS (1991). The effect of food processing on phytate hydrolysis and availability of iron and zinc. In Nutritional and toxicological consequences of food processing (pp. 499-508). Springer US.

112.Santos-Buelga C and Scalbert A (2000). Proanthocyanidins and tannin like compounds - nature, occurrence, dietary intake and effects on nutrition and health. Journal of the Science of Food and Agriculture, 80, $1097-1117$.

113.Saravanabavan SN, Shivanna MM and Bhattacharya S (2013). Effect of popping on sorghum starch digestibility and predicted glycemic index. Journal of Food Science and Technology, 50(2), 387-392.

114.Schober TJ, Bean SR and Boyle DL (2007). Gluten-free sorghum bread improved by sourdough fermentation: biochemical, rheological, and microstructural background. Journal of Agricultural and Food Chemistry, 55(13), 5137-5146.

115.Schoustra SE, Kasase C, Toarta C, Kassen R and Poulain AJ (2013). Microbial community structure of three traditional zambian fermented products: mabisi, chibwantu and munkoyo. PloS one, 8(5), e63948.

116.Sekwati-Monang B and Gänzle MG (2011). Microbiological and chemical characterisation of ting, a sorghumbased sourdough product from Botswana. International Journal of Food Microbiology, 150(2), 115-121.

117.Shin SI, Choi HJ, Chung KM, Hamaker BR, Park KH and Moon TW (2004). Slowly digestible starch from debranched waxy sorghum starch: preparation and properties. Cereal Chemistry, 81(3), 404-408.

118.Singh J, Dartois A and Kaur L (2010). Starch digestibility in food matrix: a review. Trends in Food Science \& Technology, 21(4), 168-180.

119.Sompong R, Siebenhandl-Ehn S, Linsberger-Martin G and Berghofer E (2011). Physicochemical and antioxidative properties of red and black rice varieties from Thailand, China and Sri Lanka. Food Chemistry, 124(1), 132-140.

120.Sulieman AME and Abdelgadir WS (2015). Isolation and Identification of Yeasts from the Different Stages of Hulu-mur Fermentation. Journal of Microbiology Research, 5(2), 71-76.

121.Svanberg U and Lorri W (1997). Fermentation and nutrient availability. Food Control, 8(5), 319-327.

122.Svanberg U, Lorri W and Sandbeag AS (1993). Lactic Fermentation of Non-Tannin and High-Tannin Cereals: Effects on In Vitro Estimation of Iron Availability and Phytate Hydrolysis. Journal of Food Science, 58(2), 408412 .

123.Svanberg U, Sjögren E, Lorri W, Svennerholm AM and Kaijser B (1992). Inhibited growth of common enteropathogenic bacteria in lactic-fermented cereal gruels. World Journal of Microbiology and Biotechnology, 8(6), 601-606.

124.Svensson L, Sekwati-Monang B, Lutz DL, Schieber A and Gänzle MG (2010). Phenolic acids and flavonoids in nonfermented and fermented red sorghum (Sorghum bicolor (L.) Moench). Journal of Agricultural and Food Chemistry, 58(16), 9214-9220.

125.Taleon V, Dykes L, Rooney WL and Rooney LW (2012). Effect of genotype and environment on flavonoid concentration and profile of black sorghum grains. Journal of Cereal Science, 56:470-475.

126.Taylor J and Taylor JRN (2002). Alleviation of the adverse effect of cooking on sorghum protein digestibility through fermentation in traditional African porridges. International Journal of Food Science and Technology, $37: 129-137$ 
127.Taylor JR and Emmambux MN (2010). Review: Developments in our understanding of sorghum polysaccharides and their health benefits. Cereal Chemistry, 87(4), 263-271.

128. Taylor JRN (2003). Overview: Importance of sorghum in Africa. In Afripro: Workshop on the Proteins of Sorghum and Millets: Enhancing Nutritional and Functional Properties for Africa, Pretoria (Vol. 2, No. 4).

129.Teshome A, Baum BR, Fahrig L, Torrance JK, Arnason TJ and Lambert JD (1997). Sorghum [Sorghum bicolor (L.) Moench] landrace variation and classification in north Shewa and south Welo, Ethiopia. Euphytica, 97(3), $255-263$.

130.Togo CA, Feresu SB and Mutukumira AN (2002). Identification of lactic acid bacteria isolated from opaque beer (Chibuku) for potential use as a starter culture.

131.Umeta M, West CE and Fufa H (2005). Content of zinc, iron, calcium and their absorption inhibitors in foods commonly consumed in Ethiopia. Journal of Food Composition and Analysis, 18(8), 803-817.

132.Unite states dept of Agriculture

http://www.indexmundi.com/agriculture/?commodity=sorghum\&graph=production. Accessed on 10th May 2016.

133.Van Rensburg SJ (1981). Epidemiological and dietary evidence for a specific nutritional predisposition to esophageal cancer. Journal of the National Cancer Institute, 67, 243-251.

134.Vieira-Dalodé G, Jespersen L, Hounhouigan J, Moller PL, Nago CM and Jakobsen M (2007). Lactic acid bacteria and yeasts associated with gowé production from sorghum in Bénin. Journal of Applied Microbiology, 103(2), 342-349.

135.Wang L, Weller CL, Schlegel VL, Carr TP and Cuppett SL (2007). Comparison of supercritical CO2 and hexane extraction of lipids from sorghum distillers grains. European Journal of Lipid Science and Technology, 109:567-574.

136.Waniska, R.D, Poe, J.H, Bandyopadhyay, R, 1989. Effects of growth conditions on grain molding and phenols in sorghum caryopsis. Journal of Cereal Science, 10, 217-225.

137.Wedad HA, El Tinay AH, Mustafa AI and Babiker EE (2008). Effect of fermentation, malt-pretreatment and cooking on antinutritional factors and protein digestibility of sorghum cultivars. Pakistan Journal of Nutrition, $7(2), 335-341$.

138.Wilson P, David,T and Sam B (2012). Microbial and biochemical changes occurring during production of traditional rwandese banana beer urwagwa. Fermentation Technology, 1: 104. doi: 10.4172/2167-7972.1000

139.Wu Y, Li X, Xiang W, Zhu C, Lin Z, Wu Y, Li J, Pandravada S, Ridder DD, Bai G, Wang ML, Trick HN, Bean SR, Tuinstra MR, Tesso TT and Yu J (2012). Presence of tannins in sorghum grains is conditioned by different natural alleles of Tannin1. Proceedings of the National Academy of Sciences, 109:10281-10286.

140.Ye JC, Chang WC, Hsieh DJY and Hsiao MW (2010). Extraction and analysis of $\beta$-sitosterol in herbal medicines. Journal of Medicinal Plants Research, 7:522-527.

141.Yousif NE and El Tinay AH (2001). Effect of fermentation on sorghum protein fractions and in vitro protein digestibility. Plant Foods for Human Nutrition, 56(2), 175-182.

142. Yousif NM, Huch M, Schuster T, Cho, GS, Dirar HA, Holzapfel WH and Franz CM (2010). Diversity of lactic acid bacteria from Hussuwa, a traditional African fermented sorghum food. Food Microbiology, 27(6), 757-768.

143.Zbasnik R, Carr T, Weller C, Hwang KT, Wang L, Cuppett S and Schlegel V (2009). Antiproliferation properties of grain sorghum dry distiller's grain lipids in caco. Journal of Agricultural and Food Chemistry 57:10435-10441.

144.Zhan, G and Hamaker BR (1998). Low $\alpha$-Amylase Starch Digestibility of Cooked Sorghum Flours and the Effect of Protein 1. Cereal Chemistry, 75(5), 710-713.

145.Zhang LZ and Liu RH (2015). Phenolic and carotenoid profiles and antiproliferative activity of foxtail millet. Food Chemistry, 174, 495-501.

146.Zweytick G and Berghofer E (2009). Chapter 10.Production of Gluten-Free Beer. Gluten-Free Food Science and Technology, Gallagher, E. (ed), John Wiley \& Sons, pp. 181-197. 